\title{
Acylation of trans-2-substituted cyclohexanols: the impact of substituent variation on the pyridine-induced reversal of diastereoselectivity
}

\author{
Sven Hackbusch and Andreas H. Franz* \\ Department of Chemistry, University of the Pacific, 3601 Pacific Avenue, Stockton, CA 95211, \\ USA. \\ E-mail: afranz@pacific.edu
}

DOI: $\underline{\text { http://dx.doi.org/10.3998/ark.5550190.p009.321 }}$

\begin{abstract}
Numerous methods for the stereoselective synthesis of chiral compounds exist in the literature, which use chiral templates or catalysts. Only in a limited number of cases have achiral catalysts been shown to significantly influence the stereochemical outcomes of reactions. Previous studies in our laboratories have revealed the achiral acyl-transfer catalyst pyridine to alter the stereochemical outcome of the reaction of racemic trans-2-substituted cyclohexanols with racemic 2-chloropropionyl chloride and cause a reversal of diastereoselectivity. The current paper presents the application of the reaction scheme to a wider number of substrates and reveals the importance of the heteroatom in the trans-2-substituent.
\end{abstract}

Keywords: Reversal of diastereoselectivity, acylation, achiral catalyst, neighboring group influence

\section{Introduction}

The precise control of stereochemistry in organic synthesis is highly desirable and the use of a single catalyst for obtaining exclusively one of multiple products of a stereoselective reaction describes an ideal scenario, which has been realized in some cases. ${ }^{1-3}$ Chiral substrates influence the stereochemical outcomes of their own transformations. ${ }^{4}$ In addition, stereoselectivity can be impacted by a number of factors, such as solvent polarity or temperature. Examples for the complete reversal of stereoselectivity based on these factors exist in the literature. ${ }^{5-7}$ In organometallic catalysis, chiral ligands can be utilized to control enantio- or diastereoselectivity. In some cases, even achiral additives have been shown to influence the stereochemical course of reactions, ${ }^{8-10}$ and $\pi-\pi$ stacking can play an important role as well. ${ }^{11,12}$ Our lab has previously shown that pyridine and derivatives thereof are able to catalyze the acylation of several racemic 
trans-2-substituted cyclohexanols, carrying e.g. tolylsulfanyl- or tolyloxy-substituents, with $( \pm)$ 2-chloro-propionyl chloride while at the same time reversing the diastereoselectivity of the reaction. ${ }^{13}$ A linear correlation between the amount of pyridine used and the diastereoselective outcome of the reaction was observed. ${ }^{14}$ The purpose of this study was to further investigate this relationship and to probe the substrate scope for the reversal of diastereoselectivity with pyridine. Here, we provide a rationale for the previously observed catalyst-loading effect and show that pyridine is able to reverse the diastereoselectivity for the reaction of a variety of trans-2substituted cyclohexanols with $( \pm)$-2-chloropropionyl chloride $(( \pm)-14)$ and $( \pm)$-2-chloro-2phenylacetyl chloride $(( \pm)-\mathbf{1 5})$ in the presence of an auxiliary base, as depicted in Scheme 1.
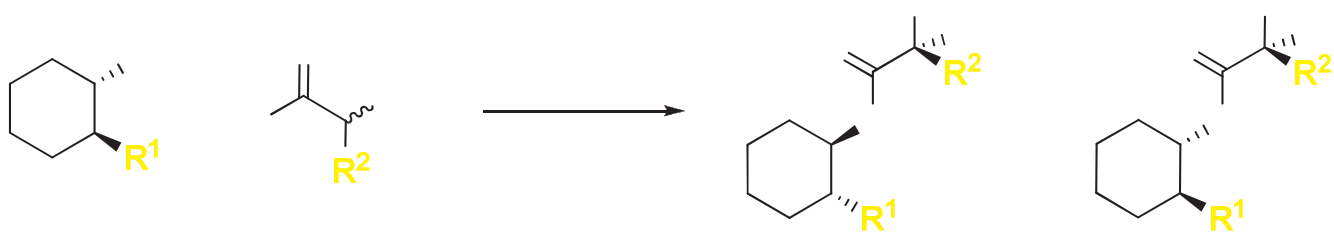

Scheme 1. Reaction scheme for the acylation of racemic trans-2-substituted cyclohexanols with racemic acyl chlorides in the (i) absence or (ii) presence of pyridine (0.1 eq) and ProtonSponge ${ }^{\circledR}$ (1.0 eq) as auxiliary base. $\mathrm{R}_{1}=$ variable (see Scheme 2$), \mathrm{R}_{2}=\mathrm{Me}(( \pm)-\mathbf{1 4}), \mathrm{R}_{2}=\mathrm{Ph}(( \pm)-\mathbf{1 5}$.

\section{Results and Discussion}

In our initial studies we focused in greater detail on the concentration-dependence of the observed diastereomeric ratio $(d r)$ on pyridine. While equimolar amounts of pyridine or dimethylaminopyridine (DMAP) led to the reversal of $d r$ compared to the uncatalyzed reaction (Table 1, Entries 1+3), use of catalytic amounts gave $d r$ 's closer to the uncatalyzed reaction (Table 1, Entry 2). Additionally, our studies had previously revealed that non-nucleophilic bulky bases such as trimethylamine gave approximately 1:1 ratio of diastereomers for the product (Table 1, Entry 4). However, when using DMAP in catalytic quantities (0.1 equivalents) with one equivalent of trimethylamine, the overall yield was improved and the observed $d r$ was comparable to the case of equimolar amounts of DMAP (Table 1, Entry 5). This effect of an auxiliary base was also seen when using a basic ion exchange resin (Amberlite IRA-400 OH; Table 1, Entry 6). 
Table 1. Removal of catalyst-load dependence through the addition of auxiliary base, using 0.1 mmol amounts of $( \pm)-\mathbf{1}$ and $( \pm)-\mathbf{1 4}$ in $1 \mathrm{~mL} \mathrm{CH}_{2} \mathrm{Cl}_{2}$ in the presence of $0.1 \mathrm{mmol}$ pyridine for $24 \mathrm{~h}$ at $\mathrm{rt}$

\begin{tabular}{ccccc}
\hline & & & & \\
Entry & Catalyst - mol\% & Isolated Yield & $\begin{array}{c}d r \\
(\mathrm{~A}: \mathrm{B})\end{array}$ \\
\hline $\mathbf{1}$ & $-/-$ & & $40 \%$ & $1: 2.0$ \\
$\mathbf{2}$ & DMAP & 10 & $35 \%$ & $1: 1.7$ \\
$\mathbf{3}$ & DMAP & 100 & $47 \%$ & $\mathbf{2 . 6} 1$ \\
$\mathbf{4}$ & $\mathrm{Et}_{3} \mathrm{~N}$ & 103 & $46 \%$ & $1: 1.1$ \\
$\mathbf{5}$ & DMAP + Et $\mathrm{H}_{3} \mathrm{~N}$ & $10+100$ & $76 \%$ & $\mathbf{2 . 8 : 1}$ \\
$\mathbf{6}$ & pyridine $+\mathrm{Amberlite}$ & $10+100$ & $35 \%$ & $\mathbf{3 . 0}: 1$ \\
\hline
\end{tabular}

The reason for this improvement in diastereoselectivity and yield through the addition of an auxiliary base is possibly the more effective neutralization of the hydrochloric acid which is released as a side-product of the reaction. When pyridine (or DMAP) is used in catalytic amounts, it is protonated by $\mathrm{HCl}$ over the course of the reaction and thus becomes unavailable for catalysis. This reverts the reaction back to the non-catalyzed reaction pathway which yields opposite diastereoselectivity. The effect is an overall reduction of the $d r$. The addition of an auxiliary base causes its protonation in the place of pyridine, leaving the latter to remain available to catalyze the acylation reaction. The effect is an overall improvement of the $d r$.

Next, the reaction conditions were optimized to give highest yield. It was noted from previous experiments that despite full consumption of $( \pm)$-2-chloropropionyl chloride only relatively low yields of the desired ester were obtained. Thus, screening of the alcohol to acyl chloride ratio revealed the 2:1 ratio thereof to give optimal ester formation for use in further reactions (Table 2).

As shown in Table 3, a small number of potential auxiliary bases were screened to find optimal conditions for the reaction of racemic trans-2-substituted cyclohexanols with racemic acyl chlorides. Based on the best combination of yield and $d r$, ProtonSponge ${ }^{\circledR}(1,8$ bis(dimethylamino)-naphthalene was chosen as a homogeneous auxiliary base to be employed in the reaction. 
Table 2. Screening of alcohol ( \pm )-1 to acyl chloride $( \pm)-\mathbf{1 4}$ ratio for optimal yield at a $0.1 \mathrm{mmol}$ scale in $1 \mathrm{~mL} \mathrm{CH} \mathrm{Cl}_{2}$ in the presence of $0.1 \mathrm{mmol}$ pyridine for $24 \mathrm{~h}$ at $\mathrm{rt}$. ( ${ }^{\mathrm{a}}$ Determined by ${ }^{1} \mathrm{H}$ NMR.)

\begin{tabular}{ccccc}
\hline Entry & ROH (eq.) & AcylCl (eq.) & $\begin{array}{c}\text { Consumption } \\
\text { (Acyl Cl) }\end{array}$ & Ester Yield \\
\hline $\mathbf{1}$ & 1.0 & 2.0 & $100 \%$ & $41 \%$ \\
$\mathbf{2}$ & 1.0 & 1.0 & $100 \%$ & $63 \%$ \\
$\mathbf{3}$ & 1.5 & 1.0 & $100 \%$ & $67 \%$ \\
$\mathbf{4}$ & 2.0 & 1.0 & $100 \%$ & $91 \%$ \\
$\mathbf{5}$ & 3.9 & 1.0 & $100 \%$ & $91 \%$ \\
\hline
\end{tabular}

With these improved catalytic reaction conditions in hand, we set out to investigate the source of the reversal of diastereoselectivity in the reaction. For this purpose, a small library of racemic trans-2-substituted cyclohexanols, carrying a variety of $\mathrm{OR}, \mathrm{SR}$ and $\mathrm{CH}_{2} \mathrm{R}$ motifs (where $\mathrm{R}=$ aryl, alkyl), was generated for substrate screening. The alcohols were allowed to react with two commercially available racemic acyl chlorides, $( \pm)$-2-chloropropionyl chloride $( \pm)-\mathbf{1 4}$ and ( \pm )-2-chloro-2-phenylacetyl chloride $( \pm)$-15.

Table 3. Screening of auxiliary base using $( \pm)-1(0.2 \mathrm{mmol})$ and $( \pm)-14(0.1 \mathrm{mmol})$ in $1 \mathrm{~mL}$ $\mathrm{CH}_{2} \mathrm{Cl}_{2}$ for $24 \mathrm{~h}$ at rt. ( ${ }^{\mathrm{a}} 1: 1$ ratio of reactants)

\begin{tabular}{ccccc}
\hline Entry & $\begin{array}{c}\text { Catalyst } \\
(10 \mathrm{~mol} \%)\end{array}$ & $\begin{array}{c}\text { Auxiliary base } \\
(1.0 \mathrm{eq})\end{array}$ & Yield & $d r(\mathrm{~A}: \mathrm{B})$ \\
\hline $\mathbf{1}$ & $-/-$ & $-/-$ & $24 \%$ & $1: \mathbf{2 . 7}$ \\
$\mathbf{2}$ & pyridine & Amberlite IRA-400 OH & $60 \%$ & $\mathbf{3 . 7}: 1$ \\
$\mathbf{3}$ & pyridine & ProtonSponge ${ }^{\circledR}$ & $82 \%$ & $\mathbf{4 . 2 : 1}$ \\
$\mathbf{4}$ & pyridine & Amberlyst A21 & $40 \%$ & $\mathbf{5 . 4 : 1}$ \\
$\mathbf{5}^{\text {a }}$ & DMAP & Et $_{3} \mathrm{~N}$ & $76 \%$ & $\mathbf{2 . 8 : 1}$ \\
$\mathbf{6}$ & pyridine & $\mathrm{NaHCO}^{2}$ & $31 \%$ & $\mathbf{3 . 6 : 1}$ \\
\hline
\end{tabular}

Compounds $( \pm)$-1-7 and ( \pm )-10 were synthesized via basic epoxide opening of cyclohexene oxide in ethanol, while the carba-analog of $( \pm)-\mathbf{3}(( \pm)-12)$ was obtained from benzyl magnesium bromide and cyclohexene oxide in THF. The epoxide opening with electron-deficient nitrophenol was unsuccessful even under basic conditions. Compound $( \pm)-8$ with a cyclohexyloxy substituent was obtained from the reaction of cyclohexene oxide and 
cyclohexanol under basic conditions. The OtBu-substitutent $(( \pm)-9)$ was installed with catalytic amounts of $\mathrm{Cu}\left(\mathrm{BF}_{4}\right)_{2}$ as activator for the epoxide opening of cyclohexane oxide with tertbutanol. Compound $( \pm)$-11 was synthesized from 1 through hydrogen peroxide oxidation in acetic acid. A second carba-analog $(( \pm)-13)$ was commercially available.

The collection of racemic trans-2-substituted cyclohexanols was then reacted with $( \pm)-2-$ chloropropionyl chloride in dichloromethane for $24 \mathrm{~h}$ at room temperature either (i) without or (ii) with the addition of pyridine and ProtonSponge ${ }^{\circledR}$ based on the established optimal reaction conditions elaborated above. Yield and $d r$ were determined from the crude reaction mixture by ${ }^{1} \mathrm{H}$ NMR analysis and the diastereomers were assigned arbitrarily as A and B, with A being the diastereomer giving the more deshielded signal of the proton signal used for the determination of the ratio of diastereomers (compare Experimental section). The results of the substrate screening are summarized in Table 4.<smiles>Cc1ccc(SC2CCCCC2C)cc1</smiles><smiles>Cc1ccc(SC2CCCCC2)cc1</smiles><smiles>C[C@@H]1CCCC[C@H]1Sc1ccccc1</smiles><smiles>C[C@H]1CCCC[C@H]1Sc1ccc2ccccc2c1</smiles><smiles>C[C@@H]1CCCC[C@H]1C</smiles><smiles>Cc1cc(C)c(C)c(C)c1</smiles><smiles>Cc1ccc(SC2CCCCC2)cc1</smiles><smiles>Cc1cccc(C)c1C[C@H]1CCCC[C@H]1C</smiles><smiles>C[C@@H]1CCCCC1C1CCCCC1</smiles><smiles>CC(C)(C)SC1CCCCC1</smiles><smiles>c1ccc(SC2CCCCC2)nc1</smiles><smiles></smiles><smiles>C[C@@H]1CCCC[C@H]1Cc1ccccc1</smiles><smiles>C[C@H]1CCCC[C@H]1C</smiles>

Scheme 2. Generated library of racemic trans-2-substituted cyclohexanols. 
Little change in the $d r$ in either (i) the absence or (ii) presence of pyridine and ProtonSponge ${ }^{\circledR}$ was observed when the aromatic moiety on the trans-2-substituent carried metaor para-substituents (Table 4, Entries 1-6). The larger naphthyloxy-substituent in ( \pm )-4 also did not lead to higher $d r$ in (ii), which indicated that extended $\pi$ - $\pi$-stacking or other electronic effects on the aromatic moiety aside from the phenyl ring were not significant.

However, $( \pm)-\mathbf{7}$ and $( \pm)-\mathbf{1 1}$ showed a strong increase in $d r$ in the catalyzed reaction. This may be a result of an increased bulk in the substrate close to the reaction center or a significant change in conformation of the substituent relative to the cyclohexanol moiety.

Table 4. Substrate screening of racemic trans-2-substituted cyclohexanols with $( \pm)-\mathbf{1 4}$ in the (i) absence or (ii) presence of pyridine $(0.01 \mathrm{mmol})$ and ProtonSponge ${ }^{\circledR}(0.1 \mathrm{mmol})$ in $1 \mathrm{~mL}$ $\mathrm{CH}_{2} \mathrm{Cl}_{2}$ for $24 \mathrm{~h}$ at $\mathrm{rt}$

\begin{tabular}{|c|c|c|c|c|c|c|c|c|c|}
\hline Entry & $\mathrm{ROH}$ & rxn cond. & NMR yield & $\begin{array}{c}d r \\
(\mathrm{~A}: \mathrm{B})\end{array}$ & Entry & $\mathrm{ROH}$ & rxn cond. & NMR yield & $\begin{array}{c}d r \\
(\mathrm{~A}: \mathrm{B})\end{array}$ \\
\hline 1 & \multirow{2}{*}{$( \pm)-1$} & I & $40 \%$ & $1: 3.2$ & 15 & \multirow{2}{*}{$( \pm)-8$} & $\mathrm{i}$ & $65 \%$ & $1: 5.2$ \\
\hline 2 & & Ii & $80 \%$ & 3.2:1 & 16 & & ii & $50 \%$ & 3.3:1 \\
\hline 3 & \multirow{2}{*}{$( \pm)-2$} & I & $24 \%$ & $1: 2.7$ & 17 & \multirow{2}{*}{$( \pm)-9$} & $\mathrm{i}$ & $94 \%$ & $1: 5.5$ \\
\hline 4 & & Ii & $82 \%$ & 4.2:1 & 18 & & ii & $77 \%$ & 1.8:1 \\
\hline 5 & \multirow{2}{*}{$( \pm)-\mathbf{3}$} & I & $22 \%$ & $1: 2.7$ & 19 & \multirow{2}{*}{$( \pm)-\mathbf{1 0}$} & $\mathrm{i}$ & $87 \%$ & 1.2:1 \\
\hline 6 & & Ii & $73 \%$ & 3.7:1 & 20 & & ii & $81 \%$ & 1.9:1 \\
\hline 7 & \multirow{2}{*}{$( \pm)-4$} & I & $22 \%$ & $1: 2.2$ & 21 & \multirow{2}{*}{$( \pm)-11$} & $\mathrm{i}$ & $0 \%$ & n.d. \\
\hline 8 & & Ii & $70 \%$ & 3.8:1 & 22 & & ii & $34 \%$ & 15:1 \\
\hline 9 & \multirow{2}{*}{$( \pm)-5$} & $\mathrm{i}$ & $16 \%$ & $1: 1.7$ & 23 & \multirow{2}{*}{$( \pm)-12$} & $\mathrm{i}$ & $53 \%$ & 2.0:1 \\
\hline 10 & & ii & $57 \%$ & 3.8:1 & 24 & & ii & $77 \%$ & $1.2: 1$ \\
\hline 11 & \multirow{2}{*}{$( \pm)-6$} & $\mathrm{i}$ & $31 \%$ & $1: 2.5$ & 25 & \multirow{2}{*}{$( \pm)-\mathbf{1 3}$} & $\mathrm{i}$ & $90 \%$ & $1: 2.2$ \\
\hline 12 & & ii & $61 \%$ & 3.7:1 & 26 & & ii & $64 \%$ & $1: 1.6$ \\
\hline 13 & \multirow{2}{*}{$( \pm)-7$} & i & $27 \%$ & $1: 3.3$ & & & & & \\
\hline 14 & & ii & $63 \%$ & $7.5: 1$ & & & & & \\
\hline
\end{tabular}

Surprisingly, it was observed that alkyloxy-substituted compounds ( \pm )-8 and ( \pm )-9 gave higher absolute $d r$ in the uncatalyzed reaction, contrary to the trend observed in aryloxysubstituted compounds. Although arguments related to electronics or sterics of these substituents and potential interactions with $( \pm)-\mathbf{1 4}$ could be made, the exact reason for this observation remains unknown and further exploration is needed to elucidate the cause. 
Compound ( \pm )-10 showed no reversal of $d r$ between (i) and (ii). This is most likely the result of the pyridine moiety on the trans-2-substituent acting as an intramolecular acyl-transfer catalyst in the absence of pyridine. The carba-analogs ( \pm )-12 and ( \pm )-13 both did not show a reversal of diastereoselectivity upon the addition of pyridine and auxiliary base. This appears to be direct consequence of the lack of a heteroatom on the trans-2-substituent. The heteroatom may significantly influence the transition state energies in the reaction with the acyl transfer catalyst relative to the reaction without it or even actively participate in the mechanism, as previously proposed. ${ }^{13}$ A heteroatom (oxygen or sulfur, in the cases above) may thus be essential for the reversal of $d r$.

Table 5. Substrate screening of selected racemic trans-2-substituted cyclohexanols with $( \pm)-\mathbf{1 5}$ in the (i) presence or (ii) absence of pyridine $(0.01 \mathrm{mmol})$ and ProtonSponge ${ }^{\circledR}(0.1 \mathrm{mmol})$ in 1 $\mathrm{mL} \mathrm{CH}_{2} \mathrm{Cl}_{2}$ for $24 \mathrm{~h}$ at $\mathrm{rt}$

\begin{tabular}{|c|c|c|c|c|}
\hline Entry & $\mathrm{ROH}$ & rxn cond. & NMR yield & $\begin{array}{c}d r \\
(\mathrm{~A}: \mathrm{B})\end{array}$ \\
\hline 1 & \multirow{2}{*}{$( \pm)-1$} & $\mathrm{i}$ & $32 \%$ & $1: 1.1$ \\
\hline 2 & & ii & $85 \%$ & 2.5:1 \\
\hline 3 & \multirow{2}{*}{$( \pm)-2$} & $\mathrm{i}$ & $13 \%$ & $1: 1.4$ \\
\hline 4 & & ii & $97 \%$ & 2.0:1 \\
\hline 5 & \multirow{2}{*}{$( \pm)-7$} & $\mathrm{i}$ & $18 \%$ & $1: 2.0$ \\
\hline 6 & & ii & $>99 \%$ & 2.8:1 \\
\hline 7 & \multirow{2}{*}{$( \pm)-8$} & $\mathrm{i}$ & $69 \%$ & $1: 6.8$ \\
\hline 8 & & ii & $>99 \%$ & $1: 10$ \\
\hline 9 & \multirow{2}{*}{$( \pm)-11$} & $\mathrm{i}$ & $4 \%$ & $1: 5.8$ \\
\hline 10 & & ii & $88 \%$ & 2.7:1 \\
\hline 11 & \multirow{2}{*}{$( \pm)-13$} & $\mathrm{i}$ & $99 \%$ & 1.7:1 \\
\hline 12 & & $\mathrm{ii}$ & $>99 \%$ & 1.1:1 \\
\hline
\end{tabular}

A small selection of racemic trans-2-substituted cyclohexanols was also subjected to ( \pm )-2chloro-2-phenylacetyl chloride ( \pm -15 in the same reaction scheme as above. The results are shown in Table 5. The initial expectation that a bulkier acyl chloride would yield higher $d r$ was not borne out by the data. Although reversal of diastereoselectivity was seen generally, the $d r$ was lower in the majority of cases with $( \pm)-\mathbf{1 5}$ than with $( \pm)-14$. The reason for this may be that the replacement of a methyl group with a phenyl group in the $\gamma$-position on the acyl chloride leads to steric crowding in the transition state, meaning that stereodifferentiation is more 
successful with less sterically demanding acyl substrate. Curiously, no reversal of diastereoselectivity was observed for $( \pm$ )-8 (Table 5, Entries 7 and 8 ). The reason for this lack of reversal is not immediately apparent and warrants further study.

In order to further investigate the reason for the reversal of $d r$ with the addition of pyridine, the transition state structures of the ester formation were computed at the B3LYP/6-31G* level of theory for $( \pm)-\mathbf{1},( \pm)-\mathbf{2}$ and $( \pm)-\mathbf{1 3}$ with $( \pm)-\mathbf{1 4}$ and the acyl-pyridinium intermediate of $( \pm)-\mathbf{1 4}$, respectively, under basic conditions (alcoholate). However, the reversal of diastereoselectivities due to the introduction of pyridine was not borne out quantitatively by the computed relative transition state energies for the different diastereomeric transition states. (For full details, transition state energies and structures, see Supplemental Material.) Modeling of the reaction at a higher level of theory and potentially with consideration of the solvent may give a more accurate representation of the experimentally observed situation, especially given the fact that the observed $d r$ 's would correspond to relatively small differences in the transition state energies. Instead, a qualitative interpretation of the computational results revealed some interesting observations that could help explain the experimentally observed reversal of $d r$.
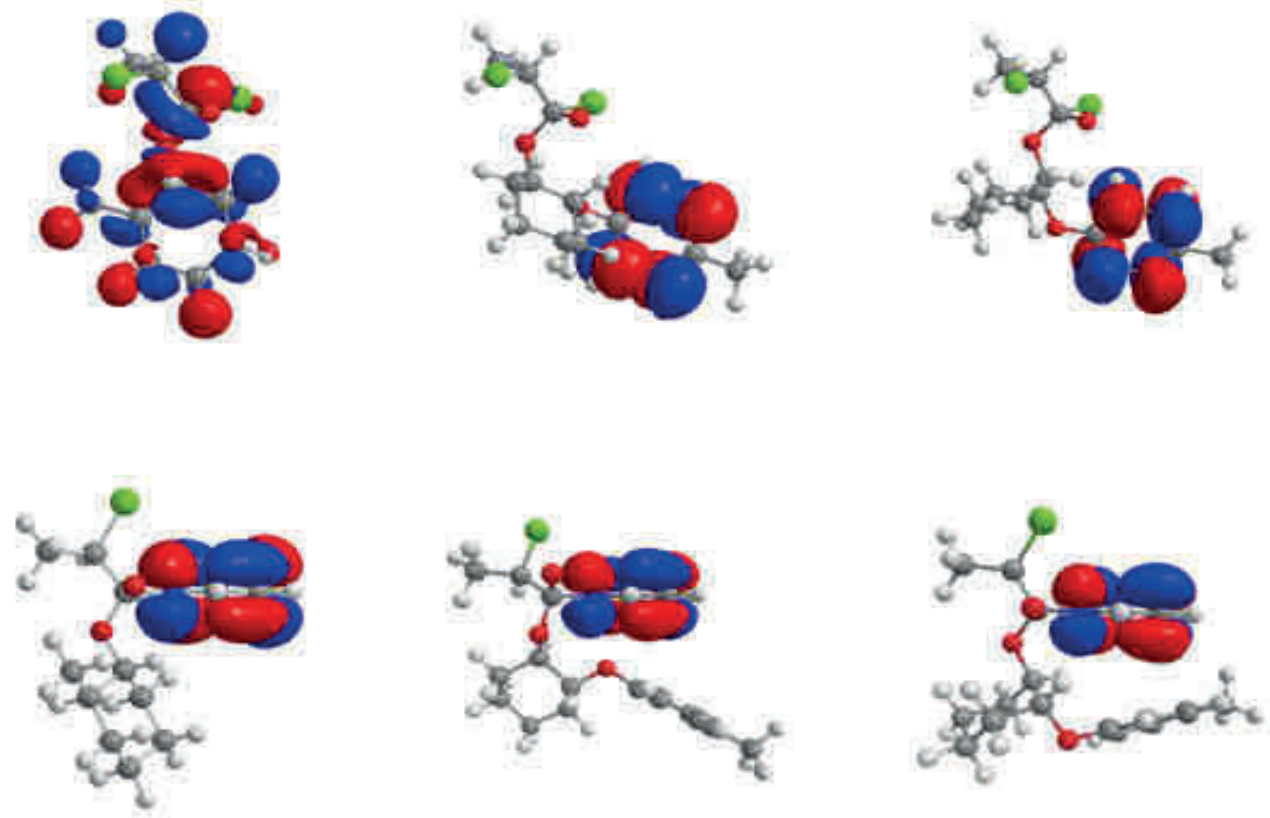

Figure 1. Representative transition state structures for the ester formation of $( \pm$ )-13 (top left structure) or $( \pm)$-2 (top right two structures) with $( \pm)$-14 or the acyl-pyridinium intermediate of $( \pm)$-14 (bottom left for $( \pm)$-2, middle and right for $( \pm)$-2) under basic conditions (alcoholate) with the LUMO shown.

Figure 1 depicts a characteristic selection of the structures of the lowest transition states found for the respective reactions of $( \pm)-2$ and $( \pm)-13$ with their LUMO shown. The structures and geometric coordinates for all diastereomeric transition states can be found in the 
Supplemental Materials. Notably, the lowest transition states had the trans-2-substituted cyclohexanol configured with both substituents in the axial position for $( \pm)-\mathbf{2}$.

The LUMO was found to be localized almost entirely in the pyridinium ring for the catalyzed reaction in all cases. In the catalyzed reaction, there appears to be an interaction of either the heteroatom or the aromatic moiety on the trans-2-substituent with the pyridinium ring, on which the LUMO is localized, causing the trans-2-substituent to be in close vicinity. This is not the case for $( \pm)-\mathbf{1 3}$, where both heteroatom and aromatic moiety are absent. As a result, no clear preference in conformation of the transition state was observed. This interaction is also notably absent in the uncatalyzed reaction and no such interaction could be inferred between the heteroatom or the aromatic moiety and the chlorine leaving group for $( \pm)-\mathbf{2}$. These computations suggest that the presence of a heteroatom and/or aromatic moiety on the trans-2-substituent of cyclohexanol causes it to interact favorably with the pyridinum species in the transition state. This overall change in conformation from the uncatalyzed to the catalyzed reaction for $( \pm)-\mathbf{2}$ may be the reason for the observed reversal in diastereoselectivity.

\section{Conclusions}

After optimization of the catalytic reaction conditions, using auxiliary base to overcome the catalyst-load dependence on the $d r$, thirteen racemic trans-2-substituted alcohols were screened with two racemic acyl chlorides for reversal of $d r$. Highest $d r$ was found with cyclohexyloxysubstituted $( \pm)-\mathbf{8}$ in the case of the uncatalyzed reaction with $( \pm)-\mathbf{1 5}(d r 1: 10)$ and in the pyridinecatalyzed reaction with the tolylsulfonyl-containing compound $( \pm)-\mathbf{1 1}$ with $( \pm)$-14 ( $d r$ 15:1). Stereoselectivity was generally higher with the less sterically demanding acyl chloride $( \pm)$-14as opposed to $( \pm)-\mathbf{1 5}$. The heteroatom on the trans-2-substituent appears to be essential for the reversal of $d r$ to be observed. Computational modeling of the reaction points to the importance of the heteroatom and/or aromatic moiety on the trans-2-substituent, as well. With further improvements to the $d r$, especially through modification close to the alcohol functionality of the cyclohexanols substrate, this method may provide valuable in the stereodivergent resolution of racemic acyl chlorides.

\section{Experimental Section}

General. Sodium borate was purchased from EMScience, Copper (II) tetrafluoroborate from Alfa Aesar, Naphthanol from Matheson Coleman \& Bell and Phenol from Mallinckrodt. All other reagents were obtained from Sigma-Aldrich and used without further purifications. Solvents were distilled prior to use. Column chromatography was performed on silica gel (Sorbent Technologies, 40-75 $\mu \mathrm{m}$ ) and fractions analyzed with TLC run on equivalent mobile phase and analyzed through UV or charring with $\mathrm{H}_{2} \mathrm{SO}_{4} / \mathrm{MeOH}$. Melting points were determined 
using a Stanford Research Systems Digimelt MPA160. ${ }^{1} \mathrm{H}-\mathrm{NMR}$ and ${ }^{13} \mathrm{C}-\mathrm{NMR}$ spectra were acquired on a JEOL ECA-600 NMR-spectrometer (600 and $150 \mathrm{MHz}$, respectively). Structural assignments were corroborated by homonuclear and heteronuclear 2D NMR methods (COSY, HMQC, HMBC and TOCSY where necessary). Accurate mass measurements were performed on a JEOL Direct Analysis in Real Time (DART) Mass Spectrometer with AccuTOF mass analyzer (Peabody, MA, USA) with polyethyleneglycol as an internal calibrant. Samples were ionized directly from a drop of solution on the tip of a glass capillary under ambient conditions without sample preparation. ${ }^{1} \mathrm{H}$ and ${ }^{13} \mathrm{C}$ NMR spectra and DART-MS spectra of all compounds are supplied in the Supplemental Material.

\section{Synthesis of $( \pm)$-trans-2-substituted cyclohexanols.}

Compound $( \pm)$-1 $[( \pm)-$ trans-2-(p-tolylsulfanyl)cyclohexanol]. To a solution of cyclohexene oxide $(9.88 \mathrm{~g}, 101 \mathrm{mmol})$ in $50 \mathrm{~mL}$ THF was added $13.5 \mathrm{~g}$ of $p$-thiocresol $(109 \mathrm{mmol}), 4 \mathrm{~g}$ of borax $(10.5 \mathrm{mmol})$ and $50 \mathrm{~mL}$ of water. The reaction mixture was heated to $50{ }^{\circ} \mathrm{C}$ and stirred for 2 hours. Then, THF was evaporated off and $150 \mathrm{~mL}$ of $5 \% \mathrm{NaOH}$ soln. (w/v) were added and stirred for $30 \mathrm{~min}$. The mixture was extracted with $\mathrm{CH}_{2} \mathrm{Cl}_{2}(4 \times 75 \mathrm{~mL})$ and the extracts were combined and dried over $\mathrm{Na}_{2} \mathrm{SO}_{4}$. Filtration and evaporation of the solvent yielded a yellow viscous liquid that crystallized at $4{ }^{\circ} \mathrm{C}$ overnight. The crude product was recrystallized from hexane to give the product as a white crystalline solid (20.3 g, 91\%). mp 45-47 ${ }^{\circ} \mathrm{C}$. ${ }^{1} \mathrm{H}$ NMR (600 $\mathrm{MHz}, \mathrm{CDCl}_{3}$ ): $\delta 7.35$ (dt, $\left.1.8 \mathrm{~Hz}, 7.8 \mathrm{~Hz}, 2 \mathrm{H}, \mathrm{Ar}\right), 7.10$ (br d, $7.8 \mathrm{~Hz}, 2 \mathrm{H}, \mathrm{Ar}$ ), 3.27 (dt, $4.2 \mathrm{~Hz}$, $9.6 \mathrm{~Hz}, \mathrm{H}-1), 3.04$ (broad s, 1H, OH), 2.66 (ddd, 4.2 Hz, $10.2 \mathrm{~Hz}, 12.0 \mathrm{~Hz}, \mathrm{H}-2), 2.33$ (s, 3H, Tolyl- $\left.\mathrm{CH}_{3}\right), 2.07\left(\mathrm{~m}, 2 \mathrm{H}, \mathrm{CH}_{2}\right), 1.66\left(\mathrm{~m}, 2 \mathrm{H}, \mathrm{CH}_{2}\right), 1.26\left(\mathrm{~m}, 4 \mathrm{H}_{2} \mathrm{CH}_{2}\right) .{ }^{13} \mathrm{C} \mathrm{NMR}(150 \mathrm{MHz}$, $\left.\mathrm{CDCl}_{3}\right): \delta 138.28\left(\mathrm{Ar}_{-} \mathrm{C}_{\mathrm{q}}\right), 134.83(\mathrm{Ar}-\mathrm{CH}), 134.60(\mathrm{Ar}-\mathrm{CH}), 129.94(\mathrm{Ar}-\mathrm{CH}), 129.64(\mathrm{Ar}-\mathrm{CH})$, $128.33\left(\mathrm{Ar}_{-} \mathrm{C}_{\mathrm{q}}\right), 71.70(\mathrm{C} 1), 56.58$ (C2), 33.66 (C6), 32.45 (C3), 26.12 (C5), 24.22 (C4), 21.05 (tolyl- $\mathrm{CH}_{3}$ ). HRMS: $\mathrm{m} / \mathrm{z}$ calculated for $\mathrm{C}_{13} \mathrm{H}_{19} \mathrm{OS}[\mathrm{M}+\mathrm{H}]^{+} 223.1152$, found $223.1161 ; \mathrm{m} / \mathrm{z}$ calculated for $\mathrm{C}_{13} \mathrm{H}_{19} \mathrm{OS}\left[\mathrm{M}+\mathrm{H}-\mathrm{H}_{2} \mathrm{O}\right]^{+} 205.1056$, found 205.1042 .

Compound $( \pm)$-2 [( \pm )-trans-2-(p-tolyloxy)cyclohexanol]. To $50 \mathrm{~mL}$ of a $0.5 \mathrm{M}$ solution of $\mathrm{Na}$ in absoluted ethanol was added cyclohexene oxide $(5.0 \mathrm{~mL}, 49.4 \mathrm{mmol})$ and $p$-cresol $(5.36 \mathrm{~g}$, $49.6 \mathrm{mmol}$ ) with stirring and the reaction was heated to $80^{\circ} \mathrm{C}$ with stirring for 24 hours. The yellow solution was then cooled, quenched with $10 \mathrm{~mL} \mathrm{H}_{2} \mathrm{O}$ and neutralized using conc. $\mathrm{HCl}$ acid. The solution was then diluted with $50 \mathrm{~mL}$ of $\mathrm{CH}_{2} \mathrm{Cl}_{2}$ and transferred to a separatory funnel. The organic layer was separated and the aqueous layer washed with $\mathrm{CH}_{2} \mathrm{Cl}_{2}(20 \mathrm{~mL})$. The combined organic layers (yellowish liquid) were washed with $\mathrm{H}_{2} \mathrm{O}(30 \mathrm{~mL})$ and sat. $\mathrm{NaCl}$ solution $(30 \mathrm{~mL})$ consecutively and then dried over $\mathrm{Na}_{2} \mathrm{SO}_{4}$. The drying agent was filtered off and the solvent evaporated to give $10.02 \mathrm{~g}$ of a tan solid. The crude product was recrystallized from hexane and combined with a second crop of crystals from the filtrate to yield $7.24 \mathrm{~g} \mathrm{(35.1}$ mmol, $71 \%$ ) of white needle-like crystals. $\mathrm{mp} 84-87^{\circ} \mathrm{C} .{ }^{1} \mathrm{H}$ NMR $\left(600 \mathrm{MHz}, \mathrm{CDCl}_{3}\right): \delta 7.08(\mathrm{~m}$, 2H, Ar), 6.85 (dt, $2.7 \mathrm{~Hz}, 8.4 \mathrm{~Hz}, 2 \mathrm{H}, \mathrm{Ar}$ ), 3.93 (ddd, $4.2 \mathrm{~Hz}, 8.4 \mathrm{~Hz}, 10.2 \mathrm{~Hz}, \mathrm{H}-1$ ), 3.70 (ddd, $4.8 \mathrm{~Hz}, 8.4 \mathrm{~Hz}, 10.8 \mathrm{~Hz}, \mathrm{H}-2), 2.43$ (broad s, 1H, OH), 2.29 (s, 3H, Tolyl- $\mathrm{CH}_{3}$ ), 2.11 (m, 2H, $\mathrm{CH} 2), 1.74\left(\mathrm{~m}, 2 \mathrm{H}, \mathrm{CH}_{2}\right), 1.33\left(\mathrm{~m}, 4 \mathrm{H}, \mathrm{CH}_{2}\right) .{ }^{13} \mathrm{C} \mathrm{NMR}\left(150 \mathrm{MHz}, \mathrm{CDCl}_{3}\right): \delta 155.78\left(\mathrm{Ar}-\mathrm{C}_{\mathrm{q}}\right)$, 
$130.67\left(\mathrm{Ar}^{-} \mathrm{C}_{\mathrm{q}}\right), 130.78$ (2C, Ar-CH), 116.62 (2C, Ar-CH), 82.75 (C-1), 73.61 (C-2), 32.12, 29.34, 24.40, 24.01, 20.55 (tolyl- $\mathrm{CH}_{3}$ ). HRMS: $m / z$ calculated for $\mathrm{C}_{13} \mathrm{H}_{19} \mathrm{O}_{2}[\mathrm{M}+\mathrm{H}]^{+}$ 207.1380, found 207.1373, $\mathrm{m} / z$ calculated for $\mathrm{C}_{13} \mathrm{H}_{17} \mathrm{O}\left[\mathrm{M}+\mathrm{H}-\mathrm{H}_{2} \mathrm{O}\right]^{+}$189.1284, found 189.1278 .

Compound $( \pm)-3[( \pm)$-trans-2-(phenyloxy)cyclohexanol]. To $10 \mathrm{~mL}$ of a roughly $0.4 \mathrm{M}$ solution of $\mathrm{Na}$ in ethanol was added cyclohexene oxide $(1.0 \mathrm{~mL}, 9.9 \mathrm{mmol})$ and phenol $(0.93 \mathrm{~g}$, $10.2 \mathrm{mmol}$ ) with stirring and the reaction mixture was heated to gentle reflux with continued stirring for 24 hours. The solution was then cooled and quenched with $10 \mathrm{~mL}$ water. Then, it was neutralized using conc. $\mathrm{HCl}$ acid. The yellow liquid was then diluted with $10 \mathrm{~mL}$ of $\mathrm{CH}_{2} \mathrm{Cl}_{2}$ and transferred to a separatory funnel. The organic layer was separated and the aqueous layer washed with $\mathrm{CH}_{2} \mathrm{Cl}_{2}(2 \times 10 \mathrm{~mL})$. The combined organic layers (yellow liquid) were washed with $15 \mathrm{~mL}$ sat. $\mathrm{NaCl}$ solution and dried over $\mathrm{Na}_{2} \mathrm{SO}_{4}$. The drying agent was filtered off and the solvent evaporated to give an off-white to yellow solid. The crude product was recrystallized from hexane to yield $0.89 \mathrm{~g}(4.6 \mathrm{mmol}, 47 \%)$ of fine white crystals. $\mathrm{mp} 83-84{ }^{\circ} \mathrm{C} .{ }^{1} \mathrm{H} \mathrm{NMR}(600 \mathrm{MHz}$, $\mathrm{CDCl}_{3}$ ): $\delta 7.27(\mathrm{~m}, 2 \mathrm{H}, \mathrm{Ar}), 6.95(\mathrm{~m}, 3 \mathrm{H}, \mathrm{Ar}), 3.99$ (ddd, $\left.4.2 \mathrm{~Hz}, 8.4 \mathrm{~Hz}, 10.2 \mathrm{~Hz}, \mathrm{H}-1\right), 3.71$ (ddd, $4.8 \mathrm{~Hz}, 8.4 \mathrm{~Hz}, 10.8 \mathrm{~Hz}, \mathrm{H}-2), 2.60$ (broad s, 1H, OH), 2.15 (m, 1H, H-6a), 2.10 (m, 1H, $\mathrm{H}-3 \mathrm{a}), 1.74\left(\mathrm{~m}, 2 \mathrm{H}, \mathrm{CH}_{2}\right), 1.43-1.24\left(\mathrm{~m}, 4 \mathrm{H}, \mathrm{CH}_{2}\right) .{ }^{13} \mathrm{C} \mathrm{NMR}\left(150 \mathrm{MHz}, \mathrm{CDCl}_{3}\right): \delta 157.93(\mathrm{Ar}-$ $\mathrm{C}_{\mathrm{q}}$ ), 129.64 (2C, Ar-CH), 121.36 (1C, Ar), 116.45 (2C, Ar-CH), 82.29 (C-1), 73.55 (C-2), 32.12 (C-3), 29.28 (C-6), 24.09, 24.02. HRMS: $m / z$ calculated for $\mathrm{C}_{12} \mathrm{H}_{17} \mathrm{O}_{2}[\mathrm{M}+\mathrm{H}]^{+}$193.1224, found 193.1245, $\mathrm{m} / z$ calculated for $\mathrm{C}_{12} \mathrm{H}_{15} \mathrm{O}\left[\mathrm{M}+\mathrm{H}-\mathrm{H}_{2} \mathrm{O}\right]^{+} 175.1118$, found 175.1150 .

Compound $( \pm)-4[( \pm)$-trans-2-(napthalen-2-yloxy)cyclohexanol]. In a $100 \mathrm{~mL}$ round-bottom flask equipped with reflux condenser was placed a previously prepared solution of $\mathrm{NaOH}$ in ethanol ( $\mathrm{pH} \mathrm{14}, 18 \mathrm{~mL})$ to which was added cyclohexene oxide $(2.0 \mathrm{~mL}, 20.0 \mathrm{mmol})$ and 2naphthanol (2.95 g, $20.5 \mathrm{mmol})$. The sandcolored suspension was stirred and heated to about 90 ${ }^{\circ} \mathrm{C}$ (oil bath temperature), which caused 2-naphthanol to dissolve and gave a clear brown solution. Reaction progress was monitored via TLC $\left(\mathrm{CH}_{2} \mathrm{Cl}_{2}\right)$. After consumption of starting material, solution was allowed to cool to give a light-brown to yellow solution with off-white solid. The suspension was then diluted with $5 \mathrm{~mL}$ water and neutralized using conc. $\mathrm{HCl}$. The product was then extracted using $20 \mathrm{~mL} \mathrm{CH}_{2} \mathrm{Cl}_{2}$ and the aqueous layer washed twice with $10 \mathrm{~mL}$ $\mathrm{CH}_{2} \mathrm{Cl}_{2}$. The organic layers were combined and dried over $\mathrm{Na}_{2} \mathrm{SO}_{4}$. After filtering off the drying agent, solvent was removed to give a sandcolored solid, which was recrystallized from ethanol to yield the product as fine white needle-shaped crystals $(2.48 \mathrm{~g}, 52 \%)$. mp $136-137{ }^{\circ} \mathrm{C} .{ }^{1} \mathrm{H}$ NMR $\left(600 \mathrm{MHz}, \mathrm{CDCl}_{3}\right): \delta(\mathrm{ppm}) 7.74(\mathrm{t}, 6.6 \mathrm{~Hz}, 2 \mathrm{H}, \mathrm{Ar}), 7.40(\mathrm{~d}, 8.4 \mathrm{~Hz}, 1 \mathrm{H}, \mathrm{Ar}), 7.42$ (ddd, 1.2 Hz, $6.6 \mathrm{~Hz}, 7.8 \mathrm{~Hz}, 1 \mathrm{H}, \mathrm{Ar}), 7.32$ (ddd, $1.2 \mathrm{~Hz}, 6.6 \mathrm{~Hz}, 7.8 \mathrm{~Hz}, 1 \mathrm{H}, \mathrm{Ar}$ ), 7.21 (br d, $2.4 \mathrm{~Hz}, 1 \mathrm{H}$, Ar), 7.15 (dd, $2.4 \mathrm{~Hz}, 9.0 \mathrm{~Hz}, 1 \mathrm{H}, \mathrm{Ar}), 4.15$ (ddd, $4.8 \mathrm{~Hz}, 9.0 \mathrm{~Hz}, 10.8 \mathrm{~Hz}, \mathrm{H}-1), 3.77$ (ddd, 4.8 $\mathrm{Hz}, 8.4 \mathrm{~Hz}, 10.8 \mathrm{~Hz}, \mathrm{H}-2), 2.24$ (m, 1H, H-6), 2.12 (m, 1H, H-3), 2.00 (br s, OH), 1.77 (m, 2H, $\left.\mathrm{CH}_{2}\right), 1.44\left(\mathrm{~m}, 1 \mathrm{H}, \mathrm{CH}_{2}\right), 1.40-1.29\left(\mathrm{~m}, 3 \mathrm{H}, \mathrm{CH}_{2}\right) .{ }^{13} \mathrm{C} \mathrm{NMR}\left(150 \mathrm{MHz}, \mathrm{CDCl}_{3}\right): \delta(\mathrm{ppm})$ 155.78 (Ar, C-O, C-7), 134.58 (Ar, $\mathrm{C}_{\mathrm{q}}$ ), 129.65 (Ar, CH), 129.31 (Ar, $\mathrm{C}_{\mathrm{q}}$ ), 127.70 (Ar, CH), 126.84 (Ar, CH), 126.47 (Ar, CH), 123.91 (Ar, CH), 119.66 (Ar, CH), 109.58 (Ar, CH), 82.36 (C-1), 73.55 (C-2), 32.20 (C-3), 29.20 (C-6), 24.10 (C-4), 24.01 (C-5). HRMS: $m / z$ calculated for 
$\mathrm{C}_{16} \mathrm{H}_{19} \mathrm{O}_{2}[\mathrm{M}+\mathrm{H}]^{+}$243.1380, found 243.1409. $\mathrm{m} / z$ calculated for $\mathrm{C}_{16} \mathrm{H}_{17} \mathrm{O}\left[\mathrm{M}+\mathrm{H}-\mathrm{H}_{2} \mathrm{O}\right]^{+}$ 225.1285, found 225.1278.

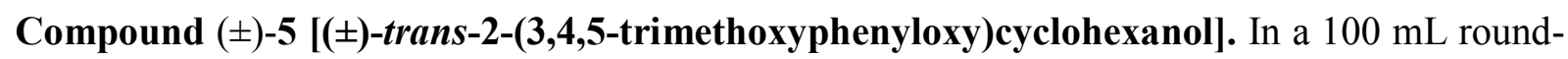
bottom flask added $1.50 \mathrm{~mL}$ cyclohexene oxide $(14.8 \mathrm{mmol})$ and $2.69 \mathrm{~g}$ of 3,4,5trimethoxyphenol (14.6 mmol) in $20 \mathrm{~mL}$ of previously prepared $\mathrm{NaOH}$ in $\mathrm{EtOH}$ solution $(\mathrm{pH}=$ 14). A reflux condenser was attached and the reaction heated to reflux using an oilbath. The dark brown solution was heated for 6 hours, then allowed to cool to RT. The solution was diluted with $15 \mathrm{~mL} \mathrm{H}_{2} \mathrm{O}$ and then extracted using $30 \mathrm{~mL}$ of $\mathrm{CH}_{2} \mathrm{Cl}_{2}$. The aqueous layer was washed twice more using $10 \mathrm{~mL}$ of $\mathrm{CH}_{2} \mathrm{Cl}_{2}$ each and the combined organic layers were dried over $\mathrm{Na}_{2} \mathrm{SO}_{4}$. The drying agent was filtered off and solvent removed using a rotavap to give a brown viscous oil which solidified after cooling. The crude product was recrystallized from hexane to yield offwhite to tan crystals $(3.38 \mathrm{~g}, 81 \%)$. mp 76-81 ${ }^{\circ} \mathrm{C} .{ }^{1} \mathrm{H} \mathrm{NMR}\left(600 \mathrm{MHz}, \mathrm{CDCl}_{3}\right): \delta(\mathrm{ppm}) 6.19$ (s, 2H, Ar), 3.90 (m, H-2), 3.82 (s, 6H, $\left.-\mathrm{OCH}_{3}\right), 3.77$ (s, 3H, $\left.-\mathrm{OCH}_{3}\right), 3.68$ (m, H-1), 2.59 (br s, $\mathrm{OH}), 2.10\left(\mathrm{~m}, 2 \mathrm{H}, \mathrm{CH}_{2}\right), 1.74\left(\mathrm{~m}, 2 \mathrm{H}, \mathrm{CH}_{2}\right), 1.38\left(\mathrm{~m}, 1 \mathrm{H}, \mathrm{CH}_{2}\right), 1.29\left(\mathrm{~m}, 3 \mathrm{H}, \mathrm{CH}_{2}\right) .{ }^{13} \mathrm{C} \mathrm{NMR}$ $\left(150 \mathrm{MHz}, \mathrm{CDCl}_{3}\right): \delta(\mathrm{ppm}) 154.47\left(\mathrm{Ar}-\mathrm{COC}_{\mathrm{Cy}}\right), 153.80\left(2 \mathrm{C}, \mathrm{Ar}-\mathbf{C O C H}_{3}\right), 132.97(\mathrm{Ar}-$ $\left.\mathrm{COCH}_{3}\right), 94.68(2 \mathrm{C}, \mathrm{Ar}-\mathrm{CH}), 83.25(\mathrm{C}-2), 73.57(\mathrm{C}-1), 61.10\left(-\mathrm{OCH}_{3}\right), 56.22\left(2 \mathrm{C},-\mathrm{OCH}_{3}\right)$, $32.15\left(\mathrm{CH}_{2}\right), 29.54\left(\mathrm{CH}_{2}\right), 24.09\left(\mathrm{CH}_{2}\right), 23.97\left(\mathrm{CH}_{2}\right)$. HRMS: $m / z$ calculated for $\mathrm{C}_{15} \mathrm{H}_{23} \mathrm{O}_{5}[\mathrm{M}+$ $\mathrm{H}]^{+}$283.1540, found 283.1535 .

Compound $( \pm)-6[( \pm)$-trans-2-(p-tert-butyl-phenyloxy)cyclohexanol]. In a $100 \mathrm{~mL}$ roundbottom flask equipped with reflux condenser was placed a previously prepared solution of $\mathrm{Na}$ in ethanol $(0.5 \mathrm{M}, 20 \mathrm{~mL})$ to which was added cyclohexene oxide $(2.0 \mathrm{~mL}, 19.8 \mathrm{mmol})$ and $p$-tertbutylphenol (3.21 g, $21.4 \mathrm{mmol}$ ). The reaction mixture was heated to about $90{ }^{\circ} \mathrm{C}$ (oil bath temperature), giving a clear solution. Reaction progress was monitored via $\mathrm{TLC}\left(\mathrm{CH}_{2} \mathrm{Cl}_{2}\right)$ and DART-HRMS. After consumption of starting material (165 min), solution was allowed to cool to give a light-yellow solution. The solution was then diluted with $10 \mathrm{~mL}$ water and neutralized

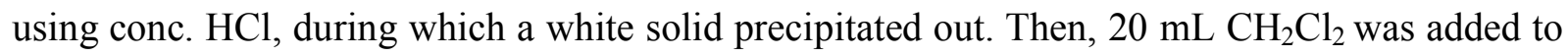
extract the product, giving two opaque colorless layers and the organic layer was separated. The aqueous layer was extracted twice with $12.5 \mathrm{~mL} \mathrm{CH}_{2} \mathrm{Cl}_{2}$. The organic layers were combined and dried over $\mathrm{Na}_{2} \mathrm{SO}_{4}$. After filtering off the drying agent, solvent was removed to give an off-white solid. The crude product was recrystallized twice from hexane to yield the product as fine white needle-shaped crystals (1.12 g, $23 \%$ ). mp 88-91 ${ }^{\circ} \mathrm{C} .{ }^{1} \mathrm{H}$ NMR $\left(600 \mathrm{MHz}, \mathrm{CDCl}_{3}\right): \delta$ (ppm) 7.28 (m, 2H, Ar), 6.87 (m, 2H, Ar), 3.95 (ddd, 4.8 Hz/9.0 Hz/10.2 Hz, 1H, H-2), 3.69 (m, 1H, H-1), 2.60 (br s, $\mathrm{OH}), 2.15\left(\mathrm{~m}, 1 \mathrm{H}, \mathrm{CH}_{2}\right), 2.09\left(\mathrm{~m}, 1 \mathrm{H}, \mathrm{CH}_{2}\right), 1.73\left(\mathrm{~m}, 2 \mathrm{H}, \mathrm{CH}_{2}\right), 1.42-1.24(\mathrm{~m}, 4 \mathrm{H}$, $\left.\mathrm{CH}_{2}\right), 1.28\left(\mathrm{~s}, 9 \mathrm{H}, \mathrm{tBu}-\mathrm{CH}_{3}\right) .{ }^{13} \mathrm{C}$ NMR $\left(150 \mathrm{MHz}, \mathrm{CDCl}_{3}\right): \delta(\mathrm{ppm}) 155.62\left(\mathrm{Ar}, \mathrm{C}_{\mathrm{q}}\right), 144.14$ $\left(\mathrm{Ar}, \mathrm{C}_{\mathrm{q}}\right), 126.42$ (2C, Ar), 115.92 (2C, Ar), 82.43 (C-2), $73.61(\mathrm{C}-1), 34.18\left(\mathrm{C}_{\mathrm{q}}, \mathrm{tBu}\right), 32.09$, $31.59(3 \mathrm{C}, \mathrm{tBu}), 29.40,24.12,24.03$. HRMS: $m / z$ calculated for $\mathrm{C}_{16} \mathrm{H}_{25} \mathrm{O}_{2}[\mathrm{M}+\mathrm{H}]^{+} 249.1850$, found 249.1835; $\mathrm{m} / \mathrm{z}$ calculated for $\mathrm{C}_{16} \mathrm{H}_{23} \mathrm{O}\left[\mathrm{M}+\mathrm{H}-\mathrm{H}_{2} \mathrm{O}\right]^{+}$231.1744, found 231.1716; m/z calculated for $\mathrm{C}_{32} \mathrm{H}_{49} \mathrm{O}_{4}[2 \mathrm{M}+\mathrm{H}]^{+} 497.3626$, found 497.3634; $\mathrm{m} / z$ calculated for $\mathrm{C}_{16} \mathrm{H}_{24} \mathrm{O}_{2}$ $[\mathrm{M}]^{+\bullet} 248.1776$, found 248.1736 . 
Compound $( \pm)-7$ [( \pm -trans-2-(2,6-dimethylphenyloxy)cyclohexanol]. To a solution of $\mathrm{Na}(0.1$ $\mathrm{g})$ in ethanol $(10 \mathrm{~mL})$ was added cyclohexene oxide $(1.0 \mathrm{~mL}, 9.9 \mathrm{mmol})$ and 2,6-dimethylphenol $(1.25 \mathrm{~g}, 10.2 \mathrm{mmol})$ with stirring and the reaction mixture was heated to gentle reflux for 24 hours. The solution was then cooled and quenched with $10 \mathrm{~mL}$ water. Then, it was neutralized using conc. $\mathrm{HCl}$ acid. The dark-brown liquid was then diluted with $10 \mathrm{~mL}$ of $\mathrm{CH}_{2} \mathrm{Cl}_{2}$ and transferred to a separatory funnel. The organic layer was separated and the aqueous layer washed with $\mathrm{CH}_{2} \mathrm{Cl}_{2}(2 \times 10 \mathrm{~mL})$ until a nearly clear yellow aqueous layer remained. The combined organic layers (dark-brown liquid) were washed with $15 \mathrm{~mL}$ sat. $\mathrm{NaCl}$ solution and dried over $\mathrm{Na}_{2} \mathrm{SO}_{4}$. The drying agent was filtered off and the solvent evaporated to give a dark-brown liquid $(2.0 \mathrm{~g})$. The crude product was purified via column chromatography (mob phase 90:10 hexane:ethyl acetate) to yield $1.52 \mathrm{~g}(6.9 \mathrm{mmol}, 80 \%)$ of a clear pale-yellow liquid $\left(\mathrm{R}_{\mathrm{f}}=0.30\right)$. ${ }^{1} \mathrm{H} \mathrm{NMR}\left(600 \mathrm{MHz}, \mathrm{CDCl}_{3}\right): \delta 6.99(\mathrm{~d}, 7.8 \mathrm{~Hz}, 2 \mathrm{H}, m-\mathrm{Ar}), 6.90$ (dd, $\left.7.2 \mathrm{~Hz}, 8.4 \mathrm{~Hz}, 1 \mathrm{H}, p-\mathrm{Ar}\right)$, 3.79 (m, 2H, H-1, H-2), 2.99 (broad s, 1H, OH), 2.29 (s, 6H, CH $), 2.09$ (m, 1H), $1.76(\mathrm{~m}, 1 \mathrm{H})$, $1.68(\mathrm{~m}, 2 \mathrm{H}), 1.4-1.25(\mathrm{~m}, 3 \mathrm{H}), 1.11$ (tq, $3.6 \mathrm{~Hz}, 13.2 \mathrm{~Hz}, 1 \mathrm{H}) .{ }^{13} \mathrm{C} \mathrm{NMR}\left(150 \mathrm{MHz}, \mathrm{CDCl}_{3}\right): \delta$ $153.33\left(\mathrm{C}_{\mathrm{q}, \mathrm{Ar}}-\mathrm{O}-\mathrm{C}\right), 131.41\left(2 \mathrm{C}, \mathrm{C}_{\mathrm{q}}\right), 129.09$ (2C, m-Ar-CH), 123.65 (1C, p-Ar-CH), 84.81, 74.62, 32.25, 29.70, 24.34, 24.13, $17.49\left(2 \mathrm{C}, \mathrm{CH}_{3}\right)$. HRMS: $\mathrm{m} / z$ calculated for $\mathrm{C}_{14} \mathrm{H}_{21} \mathrm{O}_{2}[\mathrm{M}+$ $\mathrm{H}]^{+}$221.1537, found 221.1513, $\mathrm{m} / z$ calculated for $\mathrm{C}_{14} \mathrm{H}_{19} \mathrm{O}\left[\mathrm{M}+\mathrm{H}-\mathrm{H}_{2} \mathrm{O}\right]^{+}$203.1431, found 203.1440; found 221.1513, $\mathrm{m} / \mathrm{z}$ calculated for $\mathrm{C} 14 \mathrm{H}_{24} \mathrm{NO} 2\left[\mathrm{M}+\mathrm{NH}_{4}\right]^{+}$238.1807, found 238.1846 .

Compound $( \pm)-8[( \pm)-$ trans-2-(cyclohexyloxy)cyclohexanol]. In a $100 \mathrm{~mL}$ round-bottom flask equipped with reflux condenser was placed a previously prepared solution of $\mathrm{Na}$ in cyclohexanol $(0.5 \mathrm{M}, 20 \mathrm{~mL})$ to which was added cyclohexene oxide $(2.0 \mathrm{~mL}, 19.8 \mathrm{mmol})$. The reaction mixture was heated to reflux. Reaction progress was monitored via TLC $\left(\mathrm{CH}_{2} \mathrm{Cl}_{2}\right)$. After $24 \mathrm{~h}$, solution was allowed to cool and was then diluted with $20 \mathrm{~mL}$ water and neutralized using conc.

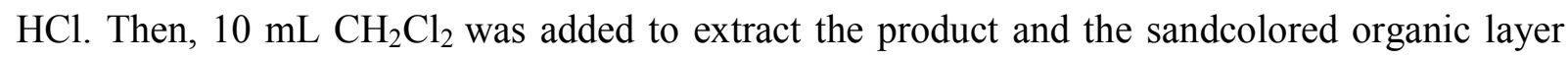
was separated. The brown-orange colored aqueous layer was extracted twice with $15 \mathrm{~mL}$ $\mathrm{CH}_{2} \mathrm{Cl}_{2}$. The organic layers were combined and washed with $20 \mathrm{~mL}$ water, then $2 \times 20 \mathrm{~mL}$ sat. $\mathrm{NaCl}$ solution and consequently dried over $\mathrm{Na}_{2} \mathrm{SO}_{4}$. After filtering off the drying agent, solvent was removed using rotavap to give a yellow liquid, from which cyclohexanol was removed using a rotavap and oil pump vacuum. The remaining yellow oily liquid was separated using column chromatography (mob. phase $\left.\mathrm{CH}_{2} \mathrm{Cl}_{2}\right)$ to give the desired product $\left(\mathrm{R}_{\mathrm{f}}=0.18\right)$ as a clear yellow oil (640.4 mg, $16 \%$ ). ${ }^{1} \mathrm{H}$ NMR (600 MHz, $\mathrm{CDCl}_{3}$ ): $\delta(\mathrm{ppm}) 3.34$ (m, 2H, H-1, H-7), 3.08 (dt, 4.2 $\mathrm{Hz}, 10.2 \mathrm{~Hz}, 1 \mathrm{H}, \mathrm{H}-2), 2.70$ (broad s, OH), 2.0-1.9 (m, 3H), $1.82(\mathrm{~m}, 1 \mathrm{H}), 1.68(\mathrm{~m}, 4 \mathrm{H}), 1.51$ (m, $1 \mathrm{H}), 1.3-1.1(\mathrm{~m}, 10 \mathrm{H}) .{ }^{13} \mathrm{C} \mathrm{NMR}\left(150 \mathrm{MHz}, \mathrm{CDCl}_{3}\right): \delta(\mathrm{ppm}) 81.39$ (C-2), $75.90(\mathrm{C}-7), 73.82$ (C-1), 34.22, 32.60, 32.03, 30.63, 25.76, 24.53, 24.51, 24.37, 24.09. HRMS: $m / z$ calculated for $\mathrm{C}_{12} \mathrm{H}_{23} \mathrm{O}_{2}[\mathrm{M}+\mathrm{H}]^{+}$199.1693, found 199.1692. $\mathrm{m} / z$ calculated for $\mathrm{C}_{12} \mathrm{H}_{21} \mathrm{O}\left[\mathrm{M}+\mathrm{H}-\mathrm{H}_{2} \mathrm{O}\right]^{+}$ 181.1587, found 181.1615 .

Compound $( \pm)-9$ [trans-2-(t-butoxy)cyclohexanol]. In a $100 \mathrm{~mL} \mathrm{RBF}$ was combined $61.8 \mathrm{mg}$ $(0.26 \mathrm{mmol})$ of $\mathrm{Cu}\left(\mathrm{BF}_{4}\right)_{2}$ in $20 \mathrm{~mL}$ dichloromethane and added $2.0 \mathrm{~mL}(19.8 \mathrm{mmol})$ of cyclohexene oxide and $7.6 \mathrm{~mL}(79.5 \mathrm{mmol})$ of freshly distilled tert-butanol and the pale blue 
solution stirred at rt. After the starting material was consumed (monitored by TLC, 90:10 hexane:ethyl acetate) after $\sim 24 \mathrm{~h}$, the reaction was quenched with $20 \mathrm{~mL}$ of water, the layers separated and the aqueous extracted with $2 \times 7 \mathrm{~mL}$ of dichloromethane. The combined org. layers were washed with $2 \times 20 \mathrm{~mL}$ sat. $\mathrm{NaCl}$ soln. and dried over $\mathrm{Na}_{2} \mathrm{SO}_{4}$. The drying agent was then filtered off and solvent evaporated to give a slightly milky liquid. TLC and DART-MS analysis showed the formation of multiple products (including a dimeric compound containing two cyclohexane rings). The desired product was isolated using column chromatography to give a clear viscous oil that solidified to form white needle-like crystals overnight at $4{ }^{\circ} \mathrm{C}(0.60 \mathrm{~g}, 18 \%$ yield). m.p. $32-34{ }^{\circ} \mathrm{C} .{ }^{1} \mathrm{H}$ NMR $\left(600 \mathrm{MHz}, \mathrm{CDCl}_{3}\right): \delta(\mathrm{ppm}) 3.30(\mathrm{~m}, 1 \mathrm{H}, \mathrm{H}-1), 3.19(\mathrm{~m}, 1 \mathrm{H}, \mathrm{H}-$ 2), 2.55 (s, OH), 2.01 (m, 1H, H-6a), 1.90 (m, 1H, H-3a), 1.66 (m, 1H, H-4a), 1.65 (s, 1H, H-5a), 1.30-1.22 (m, 4H, H-3b,4b,5b,6b), $1.22\left(\mathrm{~s}, 9 \mathrm{H}, \mathrm{CH}_{3}\right) .{ }^{13} \mathrm{C} \mathrm{NMR}\left(150 \mathrm{MHz}, \mathrm{CDCl}_{3}\right)$ : $\delta$ (ppm) $76.57(\mathrm{C}-2), 74.08(\mathrm{C}-1), 73.97\left(\mathrm{C}_{\mathrm{q}}, t \mathrm{Bu}\right), 33.51(\mathrm{C}-3), 32.17(\mathrm{C}-6), 29.16\left(3 \mathrm{C}, \mathrm{CH}_{3}\right), 24.82(\mathrm{C}-$ 5), 24.27 (C-4). HRMS: $m / z$ calculated for $\mathrm{C}_{10} \mathrm{H}_{21} \mathrm{O}_{2}[\mathrm{M}+\mathrm{H}]^{+} 173.1537$, found 173.1525.

Compound $( \pm)$-10 $[( \pm)$-trans-2-(pyridin-2-ylthio)cyclohexanol]. In a $50 \mathrm{~mL}$ round-bottom flask equipped with a reflux condenser was placed 2-mercaptopyridine $(1.22 \mathrm{~g}, 11.0 \mathrm{mmol})$ in a 1:1 mixture of THF: $\mathrm{H}_{2} \mathrm{O}(10 \mathrm{~mL})$ and added cyclohexene oxide $(1.0 \mathrm{~mL}, 9.9 \mathrm{mmol})$ and sodium tetraborate $(0.43 \mathrm{~g}, 1.1 \mathrm{mmol})$. The reaction mixture was heated to about $40{ }^{\circ} \mathrm{C}$, giving a yellow solution. After $2.5 \mathrm{~h}$, the solution was allowed to cool and then extracted with $3 \times 10 \mathrm{~mL} \mathrm{CH}_{2} \mathrm{Cl}_{2}$. The combined yellow organic layers were washed with sat. $\mathrm{NaHCO}_{3}$ soln. $(15 \mathrm{~mL})$ and dried over $\mathrm{Na}_{2} \mathrm{SO}_{4}$. After filtering off the drying agent, solvent was removed to give a yellow oil, which was purified using column chromatography (silica, 99:1 $\mathrm{CH}_{2} \mathrm{Cl}_{2}: \mathrm{MeOH}, \mathrm{R}_{\mathrm{f}} 0.18$ ) to give a clear yellow oil (0.68 g, 33\%). ${ }^{1} \mathrm{H}$ NMR (600 MHz, $\left.\mathrm{CDCl}_{3}\right): \delta(\mathrm{ppm}) 8.33$ (m, 1H, H-11), 7.48 (t, $6.9 \mathrm{~Hz}, 1 \mathrm{H}, \mathrm{H}-9$ ), 7.27 (dd, 0.6 Hz, $7.8 \mathrm{~Hz}, \mathrm{H}-8$ ), 7.00 (m, H-10), 6.12 (s, 1H, OH), 3.50 (dt, $4.2 \mathrm{~Hz}, 10.2 \mathrm{~Hz}, \mathrm{H}-2$ ), 3.40 (dt, 3.9 Hz, $11.4 \mathrm{~Hz}, \mathrm{H}-1$ ), 2.19 (br d, $12.6 \mathrm{~Hz}, \mathrm{H}-3 \mathrm{a}$ ), 2.12 (br d, 13.2 Hz, H-6a), 1.74 (d, 6.6 Hz, 2H, H-4a,5a), 1.46 (br q, $12.6 \mathrm{~Hz}, \mathrm{H}-6 \mathrm{~b}$ ), 1.37 (br q, $12.0 \mathrm{~Hz}, \mathrm{H}-$ 3b), 1.28 (q, $12.0 \mathrm{~Hz}, 2 \mathrm{H}, \mathrm{H} 4 \mathrm{~b}, 5 \mathrm{~b}) .{ }^{13} \mathrm{C}$ NMR (150 MHz, $\left.\mathrm{CDCl}_{3}\right): \delta(\mathrm{ppm}) 159.60\left(\mathrm{C}_{\mathrm{q}}, \mathrm{C}-7\right)$, 148.76 (C-11), 136.67 (C-9), 123.43 (C-8), 120.16 (C-10), 76.07 (C-2), 52.39 (C-1), 36.28 (C-3), 32.49 (C-6), 26.37, 24.25. HRMS: $m / z$ calculated for $\mathrm{C}_{11} \mathrm{H}_{16} \mathrm{NSO}[\mathrm{M}+\mathrm{H}]^{+} 210.0948$, found 210.0973. $\mathrm{m} / z$ calculated for $\mathrm{C}_{11} \mathrm{H}_{14} \mathrm{NS}\left[\mathrm{M}+\mathrm{H}-\mathrm{H}_{2} \mathrm{O}\right]^{+}$192.0842, found 192.0798.

Compound $( \pm)$-11 [( \pm -trans-2-(p-tolylsulfonyl)cyclohexanol]. (Adapted from ${ }^{15}$.) In a $50 \mathrm{~mL}$ round-bottom flask with a condenser attached, was placed $1.99 \mathrm{~g}$ of trans-2-(ptolylsulfanyl)cyclohexanol $(8.97 \mathrm{mmol})$ and $4 \mathrm{~mL}$ glacial acetic acid. $4 \mathrm{~mL}$ of hydrogen peroxide (30 wt $\%, 35.3 \mathrm{mmol}$ ) was added and the milky white mixture heated to reflux for 5 hours, after which the condenser was taken off and the clear-yellow solution heated without boiling. After another 1.5 hours, the gold-brown viscous liquid was allowed to cool to RT and left open overnight to solidify and give a tan-colored solid cake, which was recrystallized from a minimum amount of solvent $\left(4: 6 \mathrm{mix}\right.$ of $\mathrm{CHCl}_{3}$ :hexane) to yield the product as pale-yellow crystals (1.40 g, 61.4\%). m.p. 109-116 ${ }^{\circ} \mathrm{C} .{ }^{1} \mathrm{H} \mathrm{NMR}\left(600 \mathrm{MHz}, \mathrm{CDCl}_{3}\right): \delta 7.76(\mathrm{~d}, 7.8 \mathrm{~Hz}, 2 \mathrm{H}$, Ar), 7.38 (d, $8.4 \mathrm{~Hz}, 2 \mathrm{H}, \mathrm{Ar}), 3.88$ (dt, 4.8Hz, $10.2 \mathrm{~Hz}, \mathrm{H}-1), 3.83$ (s, OH), 2.95 (ddd, 4.2Hz, 10.2Hz, 12.6Hz, H-2), 2.46 (s, 3H, tolyl- $\left.\mathrm{CH}_{3}\right), 2.12$ (m, 1H, H-6), 1.89 (m, 1H, H-3), 1.70 (m, 
2H, $\mathrm{CH}_{2}$ ), 1.37-1.12 (m, 4H, H-3,H-6, $\left.\left.\mathrm{CH}_{2}\right) .{ }^{13} \mathrm{C} \mathrm{NMR} \mathrm{(150} \mathrm{MHz,} \mathrm{CDCl}_{3}\right): \delta 145.21\left(\mathrm{Ar}, \mathrm{C}_{\mathrm{q}}\right.$ ), $133.78\left(\mathrm{Ar}, \mathrm{C}_{\mathrm{q}}\right.$ ), 129.86 (Ar, 2C), 129.05 (Ar, 2C), 68.98 (C-2), 68.28 (C-1), 34.12 (C-6), 25.75, 24.56 (C-3), 23.58, 21.64 (tolyl- $\mathrm{CH}_{3}$ ). HRMS: $m / z$ calculated for $\mathrm{C}_{13} \mathrm{H}_{19} \mathrm{SO}_{3}[\mathrm{M}+\mathrm{H}]^{+} 255.1050$, found 255.1079 .

Compound $( \pm)$-12 $\left[( \pm)\right.$-trans-2-benzylcyclohexanol]. (Adapted from ${ }^{16}$.) In a $50 \mathrm{~mL}$ 3-neck flask with condenser, dropping funnel and bubbler attached, placed $0.61 \mathrm{~g}$ magnesium ribbon pieces and flushed with $\mathrm{N}_{2}$. Added $18 \mathrm{~mL}$ dry THF, then slowly added $1.2 \mathrm{~mL}$ benzyl bromide (in $8 \mathrm{~mL}$ dry THF) through the dropping funnel. Cooled on ice, then let stir at RT for $2 \mathrm{~h}$. To the slushy gray reaction mixture was added $0.7 \mathrm{~mL}$ cyclohexene oxide (in $5 \mathrm{~mL}$ THF) dropwise while cooling on ice. After $\sim 15 \mathrm{~min}$, allowed the dark gray colored reaction mixture to stir at $\mathrm{rt}$ overnight. Quenched with $20 \mathrm{~mL} \mathrm{H}_{2} \mathrm{O}$, then filtered into a separatory funnel and extracted the aqueous with ethyl acetate $(3 \times 20 \mathrm{~mL})$. The combined organic layers were washed with $20 \mathrm{~mL}$ sat. $\mathrm{NaCl}$ solution and then dried over $\mathrm{MgSO}_{4}$. After evaporation of solvent, a pale yellow oil was retained, which was separated via column chromatography (mob. phase gradient 9:1 - 8:2 hexane:ethyl acetate) to isolate the product as white needle-like crystals $(78 \mathrm{mg}, 6 \%)$ after evaporation of eluent $\left(\mathrm{R}_{\mathrm{f}}=0.18\right.$, 9:1 hexane:ethyl acetate). mp $73-75{ }^{\circ} \mathrm{C} .{ }^{1} \mathrm{H}$ NMR $(600 \mathrm{MHz}$, $\left.\mathrm{CDCl}_{3}\right): \delta 7.27(\mathrm{~m}, 2 \mathrm{H}), 7.18(\mathrm{~m}, 3 \mathrm{H}), 3.29(\mathrm{dt}, 4.8 \mathrm{~Hz}, 9.6 \mathrm{~Hz}, \mathrm{H}-1), 3.16$ (dt, $13.8 \mathrm{~Hz}, 5.4 \mathrm{~Hz}$, 1H, Benzyl-CH $\mathrm{CH}_{2}, 2.35(\mathrm{~m}, 1 \mathrm{H}$, Benzyl-CH$), 1.97(\mathrm{~m}, 1 \mathrm{H}), 1.71(\mathrm{~m}, 1 \mathrm{H}), 1.63(\mathrm{~m}, 1 \mathrm{H}), 1.57(\mathrm{~m}$, 1H), $1.50(\mathrm{~m}, 1 \mathrm{H}, \mathrm{H}-2), 1.43(\mathrm{~s}, 1 \mathrm{H}, \mathrm{OH}), 1.26(\mathrm{~m}, 2 \mathrm{H}), 1.08(\mathrm{~m}, 1 \mathrm{H}), 0.90(\mathrm{~m}, 1 \mathrm{H}) .{ }^{13} \mathrm{C} \mathrm{NMR}$ $\left(150 \mathrm{MHz}, \mathrm{CDCl}_{3}\right): \delta 140.84\left(\mathrm{C}_{\mathrm{q}, \mathrm{Ar}}\right), 129.50(2 \mathrm{C}, \mathrm{Ar}-\mathrm{CH}), 128.26(2 \mathrm{C}, \mathrm{Ar}-\mathrm{CH}), 125.83(1 \mathrm{C}$, Ar-CH), 74.65 (C-1), 47.13 (C-2), 39.10 (C-7), 35.93, 30.03, 25.51, 24.99. HRMS: $m / z$ calculated for $\mathrm{C}_{13} \mathrm{H}_{19} \mathrm{O}[\mathrm{M}+\mathrm{H}]^{+} 191.1431$, found $191.1433, \mathrm{~m} / z$ calculated for $\mathrm{C}_{13} \mathrm{H}_{17}[\mathrm{M}+\mathrm{H}-$ $\left.\mathrm{H}_{2} \mathrm{O}\right]^{+} 173.1325$, found 173.1319; $m / z$ calculated for $\mathrm{C}_{13} \mathrm{H}_{22} \mathrm{NO}\left[\mathrm{M}+\mathrm{NH}_{4}\right]^{+}$208.1701, found 208.1712; $\mathrm{m} / z$ calculated for $\mathrm{C}_{26} \mathrm{H}_{37} \mathrm{O}_{2}[2 \mathrm{M}+\mathrm{H}]^{+}$381.2789, found 381.2769.

\section{Acylation reactions.}

General procedure. Racemic trans-2-substituted cyclohexanols $( \pm)-\mathbf{1 - 1 3}(0.2 \mathrm{mmol})$ were dissolved in $1 \mathrm{~mL}$ of solvent $\left(\mathrm{CH}_{2} \mathrm{Cl}_{2}\right)$. If applicable, pyridine $(0.8 \mu \mathrm{L}, 0.01 \mathrm{mmol})$ was added immediately afterwards together with one equivalent of ProtonSponge ${ }^{\circledR}(21 \mathrm{mg}, 0.1 \mathrm{mmol})$. The reaction was initiated by the addition of $( \pm)$-2-chloropropionyl chloride $( \pm)$-14 or $( \pm)$-2-chloro-2phenylacetyl chloride $( \pm)$-15 $(0.1 \mathrm{mmol}$ respectively). The reaction mixtures were stirred at $\mathrm{rt}$ for 24 hours and then evaporated to remove solvent $\left(\mathrm{N}_{2}\right.$ flow). The crude reaction mixtures were then immediately taken up in $\mathrm{CDCl} 3$ for ${ }^{1} \mathrm{H}$ NMR analysis. After this, the acylation product of the reactions was isolated via column chromatography (mob. phase hexane:ethyl acetate or $\mathrm{CH}_{2} \mathrm{Cl}_{2}$, see below) for full characterization.

Compound $( \pm)$-16 [( \pm )-(trans-2-(p-tolylsulfanyl)cyclohexyl) 2-chloropropanoate]. Mixture of diastereomers (ratio of diastereomers determined using quartet signals for $\mathrm{CH}\left(\mathrm{CH}_{3}\right) \mathrm{Cl}$ at 4.30 $4.21 \mathrm{ppm}$ ). Isolated via column chromatography ( $\mathrm{Rf} 0.41,95: 5$ hexane:ethyl acetate). Clear pale yellow oil. ${ }^{1} \mathrm{H}-\mathrm{NMR}\left(600 \mathrm{MHz}, \mathrm{CDCl}_{3}\right): \delta(\mathrm{ppm}) 7.30$ (m, 2H, Ar), 7.15 (m, 2H, Ar), 4.80 (dt, $4.2 \mathrm{~Hz}, 9.0 \mathrm{~Hz}, \mathrm{H}-1), 4.30 / 4.26$ (q, $\left.10.2 \mathrm{~Hz}, 1 \mathrm{H}, \mathrm{CH}\left(\mathrm{CH}_{3}\right) \mathrm{Cl}\right), 3.10$ (dt, 4.2 Hz, 9.6 Hz, H-2), $2.32\left(\mathrm{~s}, 3 \mathrm{H}\right.$, tolyl- $\left.\mathrm{CH}_{3}\right), 2.05(\mathrm{~m}, 2 \mathrm{H}, \mathrm{H}-3 \mathrm{a}), 1.70(\mathrm{~m}, 2 \mathrm{H}), 1.67 / 1.65(\mathrm{~d}, 10.2 \mathrm{~Hz}, 3 \mathrm{H}$, 
$\left.\mathrm{CH}\left(\mathrm{CH}_{3}\right) \mathrm{Cl}\right), 1.48-1.38$ (m, 2H, H-6a,b), 1.38-1.23 (m, 2H, $\left.\mathrm{CH}_{2}, \mathrm{H}-3 \mathrm{~b}\right) .{ }^{13} \mathrm{C}$ NMR $(150 \mathrm{MHz}$, $\left.\mathrm{CDCl}_{3}\right): \delta 169.47 / 169.33(\mathrm{C}=\mathrm{O}), 137.63 / 137.61\left(\mathrm{Ar}-\mathrm{C}_{\mathrm{q}}\right), 133.54 / 133.45(\mathrm{Ar}, 2 \mathrm{C}), 130.10 / 130.05$ $\left(\mathrm{Ar}-\mathrm{C}_{\mathrm{q}}\right), 129.73 / 129.70(\mathrm{Ar}, 2 \mathrm{C}), 76.39 / 76.26(\mathrm{C}-1), 53.07 / 52.78\left(\mathbf{C H}\left(\mathrm{CH}_{3}\right) \mathrm{Cl}\right), 50.24 / 50.17(\mathrm{C}-$ 2), 31.58/31.40 (C-6), 30.82/30.55 (C-3), 24.86/24.64, 23.42/23.27 (CH( $\left.\left.\mathbf{C H}_{3}\right) \mathrm{Cl}\right), 21.69 / 21.54$, 21.15 (tolyl- $\mathrm{CH}_{3}$ ). HRMS: $\mathrm{m} / z$ calculated for $\mathrm{C}_{16} \mathrm{H}_{21} \mathrm{ClO}_{2} \mathrm{~S}[\mathrm{M}]^{+} 312.0951$, found $312.0935 ; \mathrm{m} / \mathrm{z}$ calculated for $\mathrm{C}_{13} \mathrm{H}_{19} \mathrm{~S}\left[\mathrm{M}+\mathrm{H}-\mathrm{HO}_{2} \mathrm{C}-\mathrm{CH}\left(\mathrm{CH}_{3}\right) \mathrm{Cl}\right]^{+} 205.1046$, found 205.1016.

Compound $( \pm)-17 \quad[( \pm)-($ trans-2-(p-tolyloxy)cyclohexyl) 2-chloropropanoate]. Mixture of diastereomers (ratio of diastereomers determined using quartet signals for $\mathrm{CH}\left(\mathrm{CH}_{3}\right) \mathrm{Cl}$ at 4.30 $4.26 \mathrm{ppm}$ ). Isolated via column chromatography (Rf 0.37, 95:5 hexane:ethyl acetate). ${ }^{1} \mathrm{H}$ NMR (600 MHz, CDCl $): \delta 7.06$ (m, 2H, Ar), 6.84 (m, 2H, Ar), 5.02 (ddd, 4.2 Hz, 7.8 Hz, 9.6 Hz, H1), 4.30/4.26 (q, 7.2 Hz, CH( $\left.\mathrm{CH}_{3}\right) \mathrm{Cl}$ ), 4.19 (ddd, $\left.4.2 \mathrm{~Hz}, 7.8 \mathrm{~Hz}, 9.0 \mathrm{~Hz}, \mathrm{H}-2\right), 2.27$ (s, 3H, tolyl$\left.\mathrm{CH}_{3}\right), 2.10(\mathrm{~m}, 2 \mathrm{H}), 1.76(\mathrm{~m}, 2 \mathrm{H}), 1.59 / 1.56\left(\mathrm{~d}, 7.2 \mathrm{~Hz}, 3 \mathrm{H}, \mathrm{CH}\left(\mathrm{CH}_{3}\right) \mathrm{Cl}\right), 1.55-1.24(\mathrm{~m}, 4 \mathrm{H})$. ${ }^{13} \mathrm{C}$ NMR $\left(150 \mathrm{MHz}, \mathrm{CDCl}_{3}\right): \delta 169.70(\mathrm{C}=\mathrm{O}), 155.99\left(\mathrm{Ar}-\mathrm{C}_{\mathrm{q}}\right), 130.62\left(\mathrm{Ar}-\mathrm{C}_{\mathrm{q}}\right), 129.99(2 \mathrm{C}, \mathrm{Ar}-$ $\mathrm{CH}), 116.40$ (2C, Ar-CH), $77.53(\mathrm{C}-2), 75.77(\mathrm{C}-1), 52.96\left(\mathbf{C H}\left(\mathrm{CH}_{3}\right) \mathrm{Cl}\right), 29.65,29.30,23.03$, 22.88, $21.58\left(\mathrm{CH}\left(\mathrm{CH}_{3}\right) \mathrm{Cl}\right), 20.59$ (tolyl- $\left.\mathrm{CH}_{3}\right)$. HRMS: $m / z$ calculated for $\mathrm{C}_{16} \mathrm{H}_{22} \mathrm{ClO}_{3}[\mathrm{M}+\mathrm{H}]^{+}$ 297.1252, found 297.1200, $\mathrm{m} / z$ calculated for $\mathrm{C}_{13} \mathrm{H}_{17} \mathrm{O}\left[\mathrm{M}+\mathrm{H}-\mathrm{HO}_{2} \mathrm{C}-\mathrm{CH}\left(\mathrm{CH}_{3}\right) \mathrm{Cl}\right]^{+} 189.1284$, found 189.1257.

Compound $( \pm)-18 \quad[( \pm)-($ trans-2-(phenyloxy)cyclohexyl 2-chloropropanoate]. Mixture of diastereomers (ratio of diastereomers determined using quartet signals for $\mathrm{CH}\left(\mathrm{CH}_{3}\right) \mathrm{Cl}$ at 4.27/4.23 ppm). Isolated via column chromatography ( $\operatorname{Rf} 0.36,95: 5$ hexane:ethyl acetate). Clear yellow oil. ${ }^{1} \mathrm{H}$ NMR $\left(600 \mathrm{MHz}, \mathrm{CDCl}_{3}\right): \delta(\mathrm{ppm}) 7.25(\mathrm{~m}, 2 \mathrm{H}, \mathrm{Ar}), 6.93(\mathrm{~m}, 3 \mathrm{H}, \mathrm{Ar}), 5.03$ (ddd, $4.8 \mathrm{~Hz}, 8.4 \mathrm{~Hz}, 9.6 \mathrm{~Hz}, \mathrm{H}-1), 4.27$ (m, H-2), 4.27/4.23 (q, 7.2 Hz, CH(CH$) \mathrm{Cl}$ ), 2.27 (s, 3H, tolyl- $\left.\mathrm{CH}_{3}\right), 2.10(\mathrm{~m}, 2 \mathrm{H}), 1.76(\mathrm{~m}, 2 \mathrm{H}), 1.57 / 1.53\left(\mathrm{~d}, 7.2 \mathrm{~Hz}, 3 \mathrm{H}, \mathrm{CH}\left(\mathrm{CH}_{3}\right) \mathrm{Cl}\right), 1.6-1.2(\mathrm{~m}, 4 \mathrm{H})$. ${ }^{13} \mathrm{C} \mathrm{NMR}\left(150 \mathrm{MHz}, \mathrm{CDCl}_{3}\right): \delta 169.56(\mathrm{C}=\mathrm{O}), 158.16\left(\mathrm{Ar}-\mathrm{C}_{\mathrm{q}}\right), 129.56(2 \mathrm{C}, \mathrm{Ar}-\mathrm{CH}), 121.26(\mathrm{C}$, Ar-CH), 116.32/116.19 (2C, Ar-CH), 77.13 (C-1), 75.79 (C-2), $52.93\left(\mathbf{C H}\left(\mathrm{CH}_{3}\right) \mathrm{Cl}\right), 29.65$, 29.32, 23.02, 22.89, $21.54\left(\mathrm{CH}\left(\mathrm{CH}_{3}\right) \mathrm{Cl}\right)$. HRMS: $m / z$ calculated for $\mathrm{C}_{15} \mathrm{H}_{20} \mathrm{ClO}_{3}[\mathrm{M}+\mathrm{H}]^{+}$ 283.1096, found 283.1096; $\mathrm{m} / z$ calculated for $\mathrm{C}_{12} \mathrm{H}_{15} \mathrm{O}\left[\mathrm{M}+\mathrm{H}-\mathrm{HO}_{2} \mathrm{C}-\mathrm{CH}\left(\mathrm{CH}_{3}\right) \mathrm{Cl}\right]^{+} 175.1118$, found 175.1113 .

Compound $( \pm)$-19 $[( \pm)$-(trans-2-(napthalen-2-yloxy)cyclohexyl) 2-chloropropanoate]. Mixture of diastereomers (ratio of diastereomers determined using quartet signals for $\mathrm{CH}\left(\mathrm{CH}_{3}\right) \mathrm{Cl}$ at 4.30/4.24 ppm). Isolated via column chromatography ( $\mathrm{Rf}$ 0.28, 95:5 hexane:ethyl acetate). White solid. ${ }^{1} \mathrm{H}$ NMR (600 MHz, $\left.\mathrm{CDCl}_{3}\right): \delta(\mathrm{ppm}) 7.74(\mathrm{~m}, 3 \mathrm{H}, \mathrm{Ar}), 7.44(\mathrm{~m}, 1 \mathrm{H}, \mathrm{Ar})$, 7.34 (m, 1H, Ar), 7.25 (m, 1H, Ar), 7.15 (m, 1H, Ar), 5.12 (m, H-1), 4.45 (dt, 4.2 Hz, 9.0 Hz, 9.0 $\mathrm{Hz}, \mathrm{H}-2), 4.30 / 4.24$ (q, $\left.6.6 \mathrm{~Hz}, \mathrm{CH}\left(\mathrm{CH}_{3}\right) \mathrm{Cl}\right), 2.25$ (m, 1H, H-3a), 2.14 (m, 1H, H-6a), 1.81 (m, 2H), $1.55 / 1.50\left(\mathrm{~d}, 7.2 \mathrm{~Hz}, \mathrm{CH}\left(\mathrm{CH}_{3}\right) \mathrm{Cl}\right), 1.67-1.38(\mathrm{~m}, 4 \mathrm{H}) .{ }^{13} \mathrm{C} \mathrm{NMR}\left(150 \mathrm{MHz}, \mathrm{CDCl}_{3}\right): \delta$ (ppm) 169.72/169.59 (C=O), 155.97/155.94 ( $\left.\mathbf{C}_{\mathrm{Ar}}-\mathrm{O}-\mathrm{C}\right), 134.56\left(\mathrm{Ar}-\mathrm{C}_{\mathrm{q}}\right), 129.60(\mathrm{Ar}-\mathrm{CH})$, 129.26/129.23 (Ar- $\left.\mathrm{C}_{\mathrm{q}}\right), 127.71$ (Ar-CH), 126.87/126.82 (Ar-CH), 126.49/126.44 (Ar-CH), 123.89/123.86 (Ar-CH), 119.64/119.54 (Ar-CH), 109.13/108.99 (Ar-CH), 77.41 (C-2), 75.99/75.69 (C-1), 52.88/52.76 $\left(\mathrm{CH}\left(\mathrm{CH}_{3}\right) \mathrm{Cl}\right), \quad 29.70 / 29.59, \quad 29.52 / 29.38, \quad 23.24 / 23.13$, 23.07/22.93, 21.51/21.48 $\left(\mathrm{CH}\left(\mathrm{CH}_{3}\right) \mathrm{Cl}\right)$. HRMS: $m / z$ calculated for $\mathrm{C}_{19} \mathrm{H}_{22} \mathrm{ClO}_{3}[\mathrm{M}+\mathrm{H}]^{+}$ 
333.1252, found 333.1292; $\mathrm{m} / z$ calculated for $\mathrm{C}_{16} \mathrm{H}_{17} \mathrm{O}\left[\mathrm{M}+\mathrm{H}-\mathrm{HO}_{2} \mathrm{C}-\mathrm{CH}\left(\mathrm{CH}_{3}\right) \mathrm{Cl}\right]^{+} 225.1274$, found 225.1276.

Compound $( \pm)-20 \quad[( \pm)-($ trans-2-(3,4,5-trimethoxyphenyloxy)cyclohexanol]. Mixture of diastereomers (ratio of diastereomers determined using quartet signals for $\mathrm{CH}\left(\mathrm{CH}_{3}\right) \mathrm{Cl}$ at 4.30/4.27 ppm). Isolated via column chromatography ( $\mathrm{Rf} 0.80,1: 1$ hexane:ethyl acetate). Clear colorless oil. ${ }^{1} \mathrm{H}$ NMR (600 MHz, $\mathrm{CDCl}_{3}$ ): $\delta$ (ppm) 6.20/6.19 (s, Ar, 2H), 5.0 (dt, $4.2 \mathrm{~Hz}, 8.4$ $\mathrm{Hz}, 1 \mathrm{H}, \mathrm{H}-2), 4.30 / 4.27$ (q, $\left.7.2 \mathrm{~Hz}, 1 \mathrm{H}, \mathrm{CH}\left(\mathrm{CH}_{3}\right) \mathrm{Cl}\right), 4.18(\mathrm{~m}, 1 \mathrm{H}, \mathrm{H}-1), 3.81\left(\mathrm{~s}, 6 \mathrm{H},-\mathrm{OCH}_{3}\right)$, $3.76\left(\mathrm{~s}, 3 \mathrm{H},-\mathrm{OCH}_{3}\right) 2.06\left(\mathrm{~m}, 2 \mathrm{H}, \mathrm{CH}_{2}\right), 1.74\left(\mathrm{~m}, 2 \mathrm{H}, \mathrm{CH}_{2}\right), 1.59 / 1.57(\mathrm{~d}, 6.6 \mathrm{~Hz}, 3 \mathrm{H}$, $\left.\mathrm{CH}\left(\mathrm{CH}_{3}\right) \mathrm{Cl}\right), 1.52\left(\mathrm{~m}, 1 \mathrm{H}, \mathrm{CH}_{2}\right), 1.40\left(\mathrm{~m}, 3 \mathrm{H}, \mathrm{CH}_{2}\right) .{ }^{13} \mathrm{C} \mathrm{NMR}\left(150 \mathrm{MHz}, \mathrm{CDCl}_{3}\right)$ : $\delta(\mathrm{ppm})$ 169.60/169.55 $(\mathrm{C}=\mathrm{O}), 154.68 / 154.62\left(\mathrm{C}-\mathrm{O}-\mathrm{C}_{\mathrm{Cy}}\right), 153.73\left(\mathrm{Ar}, 2 \mathrm{C}, \mathrm{C}_{\mathrm{q}}\right), 132.75\left(\mathrm{Ar}, \mathrm{C}_{\mathrm{q}}\right)$, 94.29/94.21 (Ar, 2C, CH), $77.54(\mathrm{C}-1), 75.27(\mathrm{C}-2), 61.06\left(-\mathrm{OCH}_{3}\right), 56.21\left(2 \mathrm{C},-\mathrm{OCH}_{3}\right)$, 52.84/52.72 $\left(\mathrm{CH}\left(\mathrm{CH}_{3}\right) \mathrm{Cl}\right), 29.73 / 29.60,29.17 / 29.00,22.89 / 22.71,22.80 / 22.61,21.54 / 21.47$ $\left(\mathrm{CH}\left(\mathrm{CH}_{3}\right) \mathrm{Cl}\right)$. HRMS: $m / z$ calculated for $\mathrm{C}_{18} \mathrm{H}_{26} \mathrm{ClO}_{6}[\mathrm{M}+\mathrm{H}]^{+} 373.1413$, found 373.1453.

Compound ( \pm )-21 [( \pm -(trans-2-(p-tert-butyl-phenyloxy)cyclohexyl 2-chloropropanoate]. Mixture of diastereomers (ratio of diastereomers determined using quartet signals for $\mathrm{CH}\left(\mathrm{CH}_{3}\right) \mathrm{Cl}$ at 4.27/4.24 ppm). Isolated via column chromatography ( $\mathrm{Rf} 0.35,95: 5$ hexane:ethyl acetate). ${ }^{1} \mathrm{H}$ NMR $\left(600 \mathrm{MHz}, \mathrm{CDCl}_{3}\right): \delta(\mathrm{ppm}) 7.26(\mathrm{~m}, 2 \mathrm{H}, \mathrm{Ar}), 6.86(\mathrm{~m}, 2 \mathrm{H}, \mathrm{Ar}), 5.02(\mathrm{~m}, 1 \mathrm{H}$, $\mathrm{H}-2), 4.27 / 4.24$ (q, $\left.6.6 \mathrm{~Hz}, 1 \mathrm{H}, \mathrm{CH}\left(\mathrm{CH}_{3}\right) \mathrm{Cl}\right), 4.23(\mathrm{~m}, 1 \mathrm{H}, \mathrm{H}-1), 2.13\left(\mathrm{~m}, 1 \mathrm{H}, \mathrm{CH}_{2}\right), 2.07(\mathrm{~m}, 1 \mathrm{H}$, $\left.\mathrm{CH}_{2}\right), 1.75\left(\mathrm{~m}, 2 \mathrm{H}, \mathrm{CH}_{2}\right), 1.56 / 1.53\left(\mathrm{~d}, 6.6 \mathrm{~Hz}, 3 \mathrm{H}, \mathrm{CH}\left(\mathrm{CH}_{3}\right) \mathrm{Cl}\right), 1.55-1.25\left(\mathrm{~m}, 4 \mathrm{H}, \mathrm{CH}_{2}\right), 1.28$ (s, 9H, tBu-CH 3$) .{ }^{13} \mathrm{C} \mathrm{NMR}\left(150 \mathrm{MHz}, \mathrm{CDCl}_{3}\right): \delta(\mathrm{ppm}) 169.56(\mathrm{C}=\mathrm{O}), 155.86\left(\mathrm{C}_{\mathrm{q}}, \mathrm{Ar}\right), 144.00$ $\left(\mathrm{C}_{\mathrm{q}}, \mathrm{Ar}\right), 126.31$ (Ar, 2C, CH), 115.87 (Ar, 2C, CH), $115.72\left(\mathrm{Ar}, \mathrm{C}_{\mathrm{q}}\right), 77.12(\mathrm{C}-1), 75.81(\mathrm{C}-2)$, $52.98\left(\mathrm{CH}\left(\mathrm{CH}_{3}\right) \mathrm{Cl}\right), 34.17\left(\mathrm{C}_{\mathrm{q}}, \mathrm{tBu}\right), 31.60\left(\mathrm{tBu}-\mathrm{CH}_{3}\right), 29.66,29.30,22.99,22.86,21.55$ $\left(\mathrm{CH}\left(\mathrm{CH}_{3}\right) \mathrm{Cl}\right)$. HRMS: $\mathrm{m} / z$ calculated for $\mathrm{C}_{19} \mathrm{H}_{28} \mathrm{ClO}_{3}[\mathrm{M}+\mathrm{H}]^{+} 339.1722$, found 339.1691; $\mathrm{m} / \mathrm{z}$ calculated for $\mathrm{C}_{16} \mathrm{H}_{23} \mathrm{O}\left[\mathrm{M}+\mathrm{H}-\mathrm{HO}_{2} \mathrm{C}-\mathrm{CH}\left(\mathrm{CH}_{3}\right) \mathrm{Cl}\right]^{+} 231.1744$, found 231.1729.

Compound $( \pm)$-22 $[( \pm)$-(trans-2-(2,6-dimethylphenyloxy)cyclohexyl 2-chloropropanoate]. Mixture of diastereomers (ratio of diastereomers determined using quartet signals for $\mathrm{CH}\left(\mathrm{CH}_{3}\right) \mathrm{Cl}$ at 4.29/4.24 ppm). Isolated via column chromatography (Rf 0.61, 9:1 hexane:ethyl acetate). Clear yellow oil. ${ }^{1} \mathrm{H}$ NMR $\left(600 \mathrm{MHz}, \mathrm{CDCl}_{3}\right)$ : $\delta(\mathrm{ppm}) 6.97(\mathrm{~d}, 7.2 \mathrm{~Hz}, 2 \mathrm{H}, m-\mathrm{Ar})$, 6.88 (t, $7.2 \mathrm{~Hz}, 1 \mathrm{H}$, p-Ar), 5.06 (m, H-1), 4.29/4.24 (q, $7.2 \mathrm{~Hz}, \mathrm{CH}\left(\mathrm{CH}_{3}\right) \mathrm{Cl}$ ), 4.01 (ddd, $4.5 \mathrm{~Hz}$, $8.4 \mathrm{~Hz}, 10.2 \mathrm{~Hz}, 1 \mathrm{H}, \mathrm{H}-2), 2.28 / 2.27\left(\mathrm{~s}, 6 \mathrm{H}, \mathrm{CH}_{3}\right), 2.12(\mathrm{~m}, 1 \mathrm{H}), 1.95(\mathrm{~m}, 1 \mathrm{H}), 1.72(\mathrm{~m}, 2 \mathrm{H})$, 1.63/1.62 (d, $\left.7.2 \mathrm{~Hz}, 3 \mathrm{H}, \mathrm{CH}\left(\mathrm{CH}_{3}\right) \mathrm{Cl}\right), 1.52(\mathrm{~m}, 1 \mathrm{H}), 1.40(\mathrm{~m}, 2 \mathrm{H}), 1.21(\mathrm{~m}, 1 \mathrm{H}) .{ }^{13} \mathrm{C} \mathrm{NMR}$ $\left(150 \mathrm{MHz}, \mathrm{CDCl}_{3}\right): \delta 169.56(\mathrm{C}=\mathrm{O}), 154.17\left(\mathrm{Ar}-\mathrm{C}_{\mathrm{q}}\right), 131.07\left(2 \mathrm{C}, \mathrm{Ar}-\mathrm{C}_{\mathrm{q}}\right), 129.04(2 \mathrm{C}, \mathrm{Ar}-\mathrm{CH})$, 123.43 (Ar-CH), 80.12 (C-2), 77.49 (C-1), $53.13\left(\mathbf{C H}\left(\mathrm{CH}_{3}\right) \mathrm{Cl}\right), 30.32,29.91,23.50(2 \mathrm{C}), 21.73$ $\left(\mathrm{CH}\left(\mathrm{CH}_{3}\right) \mathrm{Cl}\right), 17.36\left(2 \mathrm{C}, \mathrm{CH}_{3}\right)$. HRMS: $m / z$ calculated for $\mathrm{C}_{17} \mathrm{H}_{24} \mathrm{ClO}_{3}[\mathrm{M}+\mathrm{H}]^{+} 311.1409$, found 311.1397; m/z calculated for $\mathrm{C}_{14} \mathrm{H}_{19} \mathrm{O}\left[\mathrm{M}+\mathrm{H}-\mathrm{HO}_{2} \mathrm{C}-\mathrm{CH}\left(\mathrm{CH}_{3}\right) \mathrm{Cl}\right]^{+}$203.1431, found 203.1441; $\mathrm{m} / z$ calculated for $\mathrm{C}_{17} \mathrm{H}_{27} \mathrm{ClNO}_{3}\left[\mathrm{M}+\mathrm{NH}_{4}\right]^{+} 328.1679$, found 328.1677.

Compound $( \pm)$-23 [( \pm )-(trans-2-(cyclohexyloxy)cyclohexyl 2-chloropropanoate]. Mixture of diastereomers (ratio of diastereomers determined using quartet signals for $\mathrm{CH}\left(\mathrm{CH}_{3}\right) \mathrm{Cl}$ at $4.37 / 4.36 \mathrm{ppm}$ ). Isolated via column chromatography ( $\mathrm{Rf} 0.42, \mathrm{CH}_{2} \mathrm{Cl}_{2}$ ). Clear colorless oil. ${ }^{1} \mathrm{H}$ NMR (600 MHz, $\mathrm{CDCl}_{3}$ ): $\delta(\mathrm{ppm}) 4.72(\mathrm{ddd}, 4.2 \mathrm{~Hz}, 8.4 \mathrm{~Hz}, 9.6 \mathrm{~Hz}, 1 \mathrm{H}, \mathrm{H}-2), 4.37 / 4.36$ (q, 7.2 
$\left.\mathrm{Hz}, 1 \mathrm{H}, \mathrm{CH}\left(\mathrm{CH}_{3}\right) \mathrm{Cl}\right), 3.35$ (m, 2H, H-1, H-7), $2.01(\mathrm{~m}, 1 \mathrm{H}), 1.95(\mathrm{~m}, 1 \mathrm{H}), 1.81(\mathrm{~m}, 2 \mathrm{H}), 1.69$ $(\mathrm{m}, 3 \mathrm{H}), 1.68\left(\mathrm{~d}, 7.2 \mathrm{~Hz}, 3 \mathrm{H}, \mathrm{CH}\left(\mathrm{CH}_{3}\right) \mathrm{Cl}\right), 1.65(\mathrm{~m}, 1 \mathrm{H}), 1.50(\mathrm{~m}, 1 \mathrm{H}), 1.4-1.1(\mathrm{~m}, 9 \mathrm{H}) .{ }^{13} \mathrm{C}$ NMR $\left(150 \mathrm{MHz}, \mathrm{CDCl}_{3}\right): \delta 169.56 / 169.48(\mathrm{C}=\mathrm{O}), 77.54(\mathrm{C}-2), 77.04,76.60,52.99$ $\left(\mathrm{CH}\left(\mathrm{CH}_{3}\right) \mathrm{Cl}\right), 33.46,32.87,31.52,29.76,25.81,24.32,24.29,23.57,23.41,21.70 / 21.66$ $\left(\mathrm{CH}\left(\mathrm{CH}_{3}\right) \mathrm{Cl}\right)$. HRMS: $\mathrm{m} / z$ calculated for $\mathrm{C}_{15} \mathrm{H}_{26} \mathrm{ClO}_{3}[\mathrm{M}+\mathrm{H}]^{+} 289.1565$, found $289.1553 ; \mathrm{m} / \mathrm{z}$ calculated for $\mathrm{C}_{9} \mathrm{H}_{16} \mathrm{ClO}_{3}\left[\mathrm{M}+\mathrm{H}-\mathrm{C}_{6} \mathrm{H}_{10}\right]^{+}$207.0783, found 207.0774; $\mathrm{m} / z$ calculated for $\mathrm{C}_{12} \mathrm{H}_{21} \mathrm{O}\left[\mathrm{M}+\mathrm{H}-\mathrm{HO}_{2} \mathrm{C}-\mathrm{CH}\left(\mathrm{CH}_{3}\right) \mathrm{Cl}\right]^{+}$181.1587, found 181.1569 .

Compound $( \pm)-24[( \pm)-($ trans-2-(tert-butoxy)cyclohexyl 2-chloropropanoate]. Mixture of diastereomers (ratio of diastereomers determined using quartet signals for $\mathrm{CH}\left(\mathrm{CH}_{3}\right) \mathrm{Cl}$ at 4.36/4.34 ppm). Isolated via column chromatography ( $\mathrm{Rf}$ 0.23, 95:5 hexane:ethyl acetate). Clear pale yellow oil. ${ }^{1} \mathrm{H}$ NMR $\left(600 \mathrm{MHz}, \mathrm{CDCl}_{3}\right): \delta(\mathrm{ppm}) 4.64$ (ddt, $4.2 \mathrm{~Hz}, 9.0 \mathrm{~Hz}, 9.0 \mathrm{~Hz}$ ), 4.36/4.34 (q, $\left.6.6 \mathrm{~Hz}, \mathrm{CH}\left(\mathrm{CH}_{3}\right) \mathrm{Cl}\right), 3.48(\mathrm{~m}, 1 \mathrm{H}), 2.01(\mathrm{~m}, 1 \mathrm{H}), 1.86(\mathrm{~m}, 1 \mathrm{H}), 1.7-1.6(\mathrm{~m}, 2 \mathrm{H})$, 1.69/1.68 (d, 7.2 Hz, 3H, $\left.\mathrm{CH}\left(\mathrm{CH}_{3}\right) \mathrm{Cl}\right), 1.4-1.2(\mathrm{~m}, 4 \mathrm{H}), 1.18 / 1.17(9 \mathrm{H}, \mathrm{tBu}) .{ }^{13} \mathrm{C} \mathrm{NMR}(150$ $\left.\mathrm{MHz}, \mathrm{CDCl}_{3}\right): \delta 169.59(\mathrm{C}=\mathrm{O}), 76.97,73.93,70.41,53.05 / 52.76,32.98,29.43,28.79 / 28.72$, 23.12, 23.06, 21.89/21.52 $\left(\mathrm{CH}\left(\mathrm{CH}_{3}\right) \mathrm{Cl}\right)$. HRMS: $m / z$ calculated for $\mathrm{C}_{13} \mathrm{H}_{24} \mathrm{ClO}_{3}[\mathrm{M}+\mathrm{H}]^{+}$ 263.1409, found 263.1426; $\mathrm{m} / z$ calculated for $\mathrm{C}_{10} \mathrm{H}_{19} \mathrm{O}\left[\mathrm{M}+\mathrm{H}-\mathrm{C}_{4} \mathrm{H}_{8}\right]^{+}$207.0783, found 207.0774 .

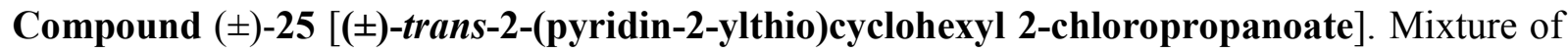
diastereomers (ratio of diastereomers determined using quartet signals for $\mathrm{CH}\left(\mathrm{CH}_{3}\right) \mathrm{Cl}$ at 4.18/4.17 ppm). Isolated via column chromatography ( $\mathrm{Rf} 0.32, \mathrm{CH}_{2} \mathrm{Cl}_{2}$ ). Clear yellow oil. ${ }^{1} \mathrm{H}$ NMR (600 MHz, CDCl $)_{3}$ : $\delta(\mathrm{ppm}) 8.41(\mathrm{~m}, 1 \mathrm{H}, \mathrm{H}-14), 7.45$ (tt, $\left.2.1 \mathrm{~Hz}, 7.5 \mathrm{~Hz}, 1 \mathrm{H}, \mathrm{H}-12\right), 7.16$ (t, $8.4 \mathrm{~Hz}, 1 \mathrm{H}, \mathrm{H}-11), 6.97$ (dd, $5.1 \mathrm{~Hz}, 7.5 \mathrm{~Hz}, 1 \mathrm{H}, \mathrm{H}-13), 4.91$ (m, 1H), 4.18/4.17 (q, $6.9 \mathrm{~Hz}$, $\left.\mathrm{CH}\left(\mathrm{CH}_{3}\right) \mathrm{Cl}\right), 4.11 / 4.08(\mathrm{dt}, 4.2 \mathrm{~Hz}, 9.6 \mathrm{~Hz}, 1 \mathrm{H}), 2.25(\mathrm{~m}, 1 \mathrm{H}), 2.08(\mathrm{~m}, 1 \mathrm{H}), 1.77(\mathrm{~m}, 1 \mathrm{H}), 1.71$ $(\mathrm{m}, 1 \mathrm{H}), 1.65(\mathrm{~m}, 2 \mathrm{H}), 1.52 / 1.51(\mathrm{~d}, 7.2 \mathrm{~Hz}, 3 \mathrm{H}, \mathrm{CH}(\mathrm{CH}) \mathrm{Cl}), 1.45(\mathrm{~m}, 2 \mathrm{H}) .{ }^{13} \mathrm{C}$ NMR $(150$ $\left.\mathrm{MHz}, \mathrm{CDCl}_{3}\right): \delta(\mathrm{ppm}) 169.51 / 169.37\left(\mathrm{C}_{\mathrm{q}}, \mathrm{C}=\mathrm{O}\right), 158.34\left(\mathrm{C}_{\mathrm{q}}, \mathrm{C}-10\right), 149.52 / 149.49(\mathrm{C}-14)$, 136.14/136.11 (H-12), 123.04/122.96 (H-11), 119.77 (H-13), 76.42/76.26, 53.00/52.80 $\left(\mathbf{C H}\left(\mathrm{CH}_{3}\right) \mathrm{Cl}\right), 45.77 / 45.61,31.71 / 31.50,30.83 / 30.68,24.93 / 24.84,23.38 / 23.31,21.51 / 21.45$ $\left(\mathrm{CH}\left(\mathrm{CH}_{3}\right) \mathrm{Cl}\right)$. HRMS: $m / z$ calculated for $\mathrm{C}_{14} \mathrm{H}_{19} \mathrm{ClNSO}_{2}[\mathrm{M}+\mathrm{H}]^{+} 300.0820$, found 300.0802 . $\mathrm{m} / z$ calculated for $\mathrm{C}_{11} \mathrm{H}_{15} \mathrm{NS}\left[\mathrm{M}+\mathrm{H}-\mathrm{HO}_{2} \mathrm{C}-\mathrm{CH}\left(\mathrm{CH}_{3}\right) \mathrm{Cl}\right]^{+} 192.0842$, found 192.0798.

Compound $( \pm)-26[( \pm)$-(trans-2-(p-tolylsulfonyl)cyclohexyl 2-chloropropanoate]. Mixture of diastereomers (ratio of diastereomers determined using quartet signals for $\mathrm{CH}\left(\mathrm{CH}_{3}\right) \mathrm{Cl}$ at 4.03/4.00 ppm). Isolated via column chromatography ( $\mathrm{Rf} 0.39,8: 2$ hexane:ethyl acetate). Offwhite solid. ${ }^{1} \mathrm{H}$ NMR (600 MHz, $\left.\mathrm{CDCl}_{3}\right): \delta(\mathrm{ppm}) 7.73(\mathrm{~d}, 8.4 \mathrm{~Hz}, 2 \mathrm{H}), 7.36(\mathrm{~d}, 7.8 \mathrm{~Hz}, 2 \mathrm{H})$, 5.06 (dt, $4.8 \mathrm{~Hz}, 10.2 \mathrm{~Hz}, \mathrm{H}-1), 4.03 / 4.00$ (q, $7.2 \mathrm{~Hz}, \mathrm{CH}\left(\mathrm{CH}_{3}\right) \mathrm{Cl}$ ), 3.27 (ddd, $4.2 \mathrm{~Hz}, 9.6 \mathrm{~Hz}$, $12.0 \mathrm{~Hz}, \mathrm{H}-2), 2.44\left(\mathrm{~s}, 3 \mathrm{H}\right.$, tolyl- $\left.\mathrm{CH}_{3}\right), 2.21(\mathrm{~m}, 1 \mathrm{H}), 2.11(\mathrm{~m}, 1 \mathrm{H}), 1.84(\mathrm{~m}, 1 \mathrm{H}), 1.73(\mathrm{~m}, 1 \mathrm{H})$, $1.59\left(\mathrm{~d}, 7.2 \mathrm{~Hz}, 3 \mathrm{H}, \mathrm{CH}\left(\mathrm{CH}_{3}\right) \mathrm{Cl}\right), 1.52(\mathrm{~m}, 1 \mathrm{H}), 1.4-1.2(\mathrm{~m}, 3 \mathrm{H}) .{ }^{13} \mathrm{C} \mathrm{NMR}\left(150 \mathrm{MHz}, \mathrm{CDCl}_{3}\right): \delta$ $168.84(\mathrm{C}=\mathrm{O}), 144.91\left(\mathrm{C}_{\mathrm{q}, \mathrm{Ar}}-\mathrm{S}\right), 135.59\left(\mathrm{C}_{\mathrm{q}}\right), 129.94(2 \mathrm{C}, \mathrm{Ar}), 128.87$ (2C, Ar), $71.78(\mathrm{C}-1)$, $65.32(\mathrm{C}-2), 53.03\left(\mathbf{C H}\left(\mathrm{CH}_{3}\right) \mathrm{Cl}\right), 31.05(\mathrm{C}-6), 25.16(\mathrm{C}-3), 23.98,23.16,21.74\left(\mathrm{CH}\left(\mathrm{CH}_{3}\right) \mathrm{Cl}\right)$, 21.65. HRMS: $m / z$ calculated for $\mathrm{C}_{16} \mathrm{H}_{22} \mathrm{ClO}_{4} \mathrm{~S}[\mathrm{M}+\mathrm{H}]^{+} 345.0922$, found 345.0938 . 
Compound $( \pm)-27 \quad[( \pm)$-(trans-2-benzylcyclohexyl) 2-chloropropanoate]. Mixture of diastereomers (ratio of diastereomers determined using quartet signals for $\mathrm{CH}\left(\mathrm{CH}_{3}\right) \mathrm{Cl}$ at 4.28/4.23 ppm). Isolated via column chromatography (Rf 0.44, 95:5 hexane:ethyl acetate). Clear colorless oil. ${ }^{1} \mathrm{H}$ NMR $\left(600 \mathrm{MHz}, \mathrm{CDCl}_{3}\right): \delta(\mathrm{ppm}) 7.21(\mathrm{~m}, 2 \mathrm{H}, \mathrm{Ph}), 7.12$ (t, $7.8 \mathrm{~Hz}, 1 \mathrm{H}, p$-Ar), 7.06 (m, 2H, Ph), 4.56 (m, 1H, H-1), 4.28/4.23 (q, 6.9 Hz, $\mathrm{CH}\left(\mathrm{CH}_{3}\right) \mathrm{Cl}$ ), 2.86 (ddd, $3.6 \mathrm{~Hz}, 13.2$ Hz, 29.4 Hz, 1H, H-7a), 2.22 (ddd, 2.4 Hz, 9.0 Hz, 12.0 Hz, H-7b), 1.96 (m, 1H), 1.88-1.65 (m, $6 \mathrm{H}), 1.65-1.50(\mathrm{~m}, 1 \mathrm{H}), 1.40-0.93(\mathrm{~m}, 4 \mathrm{H}) .{ }^{13} \mathrm{C} \mathrm{NMR}\left(150 \mathrm{MHz}, \mathrm{CDCl}_{3}\right): \delta 169.81(\mathrm{C}=\mathrm{O})$, $140.16\left(\right.$ Ar- $\left._{\mathrm{q}}\right), 129.33 / 129.28(2 \mathrm{C}, \mathrm{Ar}-\mathrm{CH}), 128.31(2 \mathrm{C}, \mathrm{Ar}-\mathrm{CH}), 126.00(\mathrm{Ar}-\mathrm{CH}), 78.73 / 78.67$ $(\mathrm{C}-1), \quad 52.98 / 52.88 \quad\left(\mathrm{CH}\left(\mathrm{CH}_{3}\right) \mathrm{Cl}\right), \quad 43.86 / 43.66 \quad(\mathrm{C}-2), \quad 38.87 / 38.71 \quad(\mathrm{C}-7), \quad 31.58 / 31.44$, 30.02/29.98, 25.01, 24.49, 21.60/21.46 $\left(\mathrm{CH}\left(\mathrm{CH}_{3}\right) \mathrm{Cl}\right)$. HRMS: $m / z$ calculated for $\mathrm{C}_{16} \mathrm{H}_{22} \mathrm{ClO}_{2}[\mathrm{M}$ $+\mathrm{H}]^{+}$281.1303, found 281.1303; $m / z$ calculated for $\mathrm{C}_{13} \mathrm{H}_{17}\left[\mathrm{M}+\mathrm{H}-\mathrm{HO}_{2} \mathrm{C}-\mathrm{CH}\left(\mathrm{CH}_{3}\right) \mathrm{Cl}\right]^{+}$ 173.1325, found 173.1297; $\mathrm{m} / z$ calculated for $\mathrm{C}_{16} \mathrm{H}_{25} \mathrm{ClNO}_{2}\left[\mathrm{M}+\mathrm{NH}_{4}\right]^{+}$298.1564, found 298.1574 .

Compound $\quad( \pm)$-28 $[( \pm)$-(trans-2-methylcyclohexyl) 2-chloropropanoate $]$ Mixture of diastereomers (ratio of diastereomers determined using doublet signals for $\mathrm{CH}\left(\mathrm{CH}_{3}\right) \mathrm{Cl}$ at 1.68/1.67 ppm). Isolated via column chromatography ( $\mathrm{Rf} 0.35,95: 5$ hexane:ethyl acetate). ${ }^{1} \mathrm{H}$ NMR (600 MHz, $\left.\mathrm{CDCl}_{3}\right): \delta 4.45$ (m, H-1), 4.37/4.36 (q, 7.2 Hz, $\left.\mathrm{CH}\left(\mathrm{CH}_{3}\right) \mathrm{Cl}\right), 1.97(\mathrm{~m}, 1 \mathrm{H})$, $1.75(\mathrm{~m}, 2 \mathrm{H}), 1.68 / 1.67$ (d, $\left.6.9 \mathrm{~Hz}, \mathrm{CH}\left(\mathrm{CH}_{3}\right) \mathrm{Cl}\right), 1.64-1.55(\mathrm{~m}, 2 \mathrm{H}), 1.35-1.20(\mathrm{~m}, 3 \mathrm{H}), 1.07$ (m, $1 \mathrm{H}), 0.91\left(\mathrm{~d}, 6.6 \mathrm{~Hz}, 2 \mathrm{H}, \mathrm{Cy}-\mathrm{CH}_{3}\right), 0.89$ (d, $\left.6.6 \mathrm{~Hz}, 1 \mathrm{H}, \mathrm{Cy}-\mathrm{CH}_{3}\right) .{ }^{13} \mathrm{C} \mathrm{NMR}\left(150 \mathrm{MHz}, \mathrm{CDCl}_{3}\right)$ : $\delta 169.84(\mathrm{C}=\mathrm{O}), 80.36 / 80.24(\mathrm{C}-1), 53.12 / 52.89\left(\mathrm{CHClCH}_{3}\right), 37.31 / 37.20,34.74,33.51,31.48$, 25.35/25.27, 24.68, 21.70/21.48 $\left(\mathrm{CHClCH}_{3}\right)$. HRMS: $m / z$ calculated for $\mathrm{C}_{10} \mathrm{H}_{18} \mathrm{ClO}_{2}[\mathrm{M}+\mathrm{H}]^{+}$ 205.0990, found 205.1040.

Compound $( \pm)$-29 $[( \pm)-($ trans-2-(p-tolylsulfanyl)cyclohexyl 2-chloro-2-phenylethanoate $]$. Mixture of diastereomers (ratio of diastereomers determined using signal for H-2 at 3.05/2.99 ppm). Isolated via column chromatography (Rf 0.58, 95:5 hexane:ethyl acetate). Clear pale yellow oil. ${ }^{1} \mathrm{H}$ NMR (600 MHz, $\left.\mathrm{CDCl}_{3}\right): \delta(\mathrm{ppm}) 7.51 / 7.42(\mathrm{~m}, 2 \mathrm{H}, \mathrm{Ph}), 7.37 / 7.33$ (m, 3H, Ph), 7.32/7.17 (dt, $2.4 \mathrm{~Hz}, 7.8 \mathrm{~Hz}, 2 \mathrm{H}, \mathrm{Tol}), 7.12 / 7.05$ (br d, $7.8 \mathrm{~Hz}, 2 \mathrm{H}, \mathrm{Tol}), 5.31 / 5.10(\mathrm{~s}, 1 \mathrm{H}$, CHClPh), 4.79/4.75 (dt, 4.2 Hz, 8.4 Hz, H-1), 3.05/2.99 (ddd, 4.2 Hz, 9.0 Hz, 10.2 Hz, H-2), 2.34/2.31 (s, 3H, tolyl-CH $\left.\mathrm{CH}_{3}\right), 2.11 / 2.05(\mathrm{~m}, 1 \mathrm{H}), 1.93(\mathrm{~m}, 1 \mathrm{H}), 1.65 / 1.58(\mathrm{~m}, 2 \mathrm{H}), 1.5-1.2(\mathrm{~m}$, 4H). ${ }^{13} \mathrm{C}$ NMR (150 MHz, $\left.\mathrm{CDCl}_{3}\right): \delta 167.57(\mathrm{C}=\mathrm{O}), 137.67\left(\mathrm{C}_{\mathrm{q}}\right), 136.17\left(\mathrm{C}_{\mathrm{q}}\right), 133.55(2 \mathrm{C}, \mathrm{Tol})$, $130.26\left(\mathrm{C}_{\mathrm{q}}\right), \quad 129.76 / 129.67 \quad(2 \mathrm{C}, \quad \mathrm{Tol}), \quad 129.30 / 129.21 \quad(\mathrm{Ph}), \quad 128.88 / 128.80 \quad(2 \mathrm{C}, \mathrm{Ph})$, 128.22/127.99 (2C, Ph), 77.38/76.35 (C-1), 59.52/59.37 (CHClPh), 50.06 (C-2), 31.33, 30.44, 24.71, 23.20, 21.22 (tolyl- $\mathrm{CH}_{3}$ ). HRMS: $m / z$ calculated for $\mathrm{C}_{21} \mathrm{H}_{24} \mathrm{ClSO}_{2}[\mathrm{M}+\mathrm{H}]^{+} 374.1107$, found 374.1101; m/z calculated for $\mathrm{C}_{13} \mathrm{H}_{17} \mathrm{~S}\left[\mathrm{M}+\mathrm{H}-\mathrm{HO}_{2} \mathrm{C}-\mathrm{CHClPh}\right]^{+}$205.1046, found 205.1036 .

Compound $( \pm)$-30 [( \pm )-(trans-2-(p-tolyloxy)cyclohexyl 2-chloro-2-phenylethanoate]. Mixture of diastereomers (ratio of diastereomers determined using signal for H-2 at 4.18/4.08 ppm). Isolated via column chromatography ( $\mathrm{Rf}$ 0.32, 95:5 hexane:ethyl acetate). Clear yellow oil. ${ }^{1} \mathrm{H}$ NMR (600 MHz, $\left.\mathrm{CDCl}_{3}\right): \delta(\mathrm{ppm}) 7.41(\mathrm{~m}, 2 \mathrm{H}, \mathrm{Ph}), 7.27$ (m, 3H, Ph), 7.07/6.99 (m, 8.4 Hz, 2H, Tol), 6.80/6.65 (dt, 8.4 Hz, 2.4 Hz, 2H, Tol), 5.30/5.23 (s, 1H, CHClPh), 5.02 (m, 1H, H-1), 
4.18/4.08 (ddd, 9.6 Hz, 8.4 Hz, 4.2 Hz, 1H, H-2), 2.30/2.27 (s, 3H, tolyl-CH ${ }_{3}$ ), $2.10(\mathrm{~m}, 1 \mathrm{H})$, $1.99(\mathrm{~m}, 1 \mathrm{H}), 1.73(\mathrm{~m}, 1 \mathrm{H}), 1.64(\mathrm{~m}, 1 \mathrm{H}), 1.55-1.24(\mathrm{~m}, 4 \mathrm{H}) .{ }^{13} \mathrm{C} \mathrm{NMR}\left(150 \mathrm{MHz}, \mathrm{CDCl}_{3}\right): \delta$ $167.78(\mathrm{C}=\mathrm{O}), 155.87\left(\mathrm{C}_{\mathrm{q}}-\mathrm{O}-\mathrm{C}, \mathrm{Tol}\right), 136.09 / 135.85\left(\mathrm{C}_{\mathrm{q}}, \mathrm{Ar}\right), 130.62 / 130.46\left(\mathrm{C}_{\mathrm{q}}, \mathrm{Ar}\right)$, 130.01/129.88 (2C, Tol-CH), 129.19/129.13 (1C, Ph-CH), 128.87/128.78 (2C, Ph-CH), 127.98 (2C, Ph-CH), 116.37/116.30 (2C, Tol-CH), 76.48 (C-2), 76.15 (C-1), 59.48/59.42 (CHClPh), 31.69, 29.64/29.48, 29.18, 22.99, 22.89, 22.77, 20.63 (tolyl- $\left.\mathrm{CH}_{3}\right)$. HRMS: $\mathrm{m} / z$ calculated for $\mathrm{C}_{21} \mathrm{H}_{24} \mathrm{ClO}_{3}[\mathrm{M}+\mathrm{H}]^{+} 359.1409$, found $359.1419 ; \mathrm{m} / \mathrm{z}$ calculated for $\mathrm{C}_{13} \mathrm{H}_{17} \mathrm{O}[\mathrm{M}+\mathrm{H}-$ $\left.\mathrm{HO}_{2} \mathrm{C}-\mathrm{CH}\left(\mathrm{CH}_{3}\right) \mathrm{Cl}\right]^{+}$189.1274, found 189.1246.

Compound $( \pm)-31 \quad[( \pm)-($ trans-2-(2,6-dimethylphenyloxy)cyclohexyl 2-chloro-2-phenylethanoate]. Mixture of diastereomers (ratio of diastereomers determined using signal for $\mathrm{H}-1$ at 5.11/5.05 ppm). Isolated via column chromatography $\left(\mathrm{R}_{\mathrm{f}} 0.54,9: 1\right.$ hexane:ethyl acetate). Pale yellow oil. ${ }^{1} \mathrm{H}$ NMR $\left(600 \mathrm{MHz}, \mathrm{CDCl}_{3}\right)$ : $\delta(\mathrm{ppm})$ 7.5-7.3 (m, 5H, Ph-CH), 7.0-6.8 (m, 3H, $\left.\mathrm{Ph}\left(\mathrm{CH}_{3}\right)_{2}-\mathrm{CH}\right), 5.30 / 5.13$ (s, $\mathrm{CH}(\mathrm{Ph}) \mathrm{Cl}$ ), 5.11/5.05 (ddd, $\left.4.8 \mathrm{~Hz}, 8.4 \mathrm{~Hz}, 10.2 \mathrm{~Hz}, \mathrm{H}-1\right), 3.94$ (m, $\mathrm{H}-2), 2.26 / 2.15\left(\mathrm{~s}, 6 \mathrm{H}, \mathrm{CH}_{3}\right), 2.13 / 2.02(\mathrm{~m}, 1 \mathrm{H}), 1.94 / 1.81(\mathrm{~m}, 1 \mathrm{H}), 1.70 / 1.61(\mathrm{~m}, 2 \mathrm{H}), 1.55-$ $1.10(\mathrm{~m}, 4 \mathrm{H}) .{ }^{13} \mathrm{C}$ NMR $\left(150 \mathrm{MHz}, \mathrm{CDCl}_{3}\right): \delta 167.75(\mathrm{C}=\mathrm{O}), 154.30\left(\mathrm{Ar}-\mathrm{C}_{\mathrm{q}}\right), 131.18 / 131.01(2 \mathrm{C}$, Ar- $\left.\mathrm{C}_{\mathrm{q}}\right), \quad 129.25 / 129.17(\mathrm{Ph}), \quad 129.05 / 128.95 \quad\left(2 \mathrm{C}, \mathrm{Ph}\left(\mathrm{CH}_{3}\right)_{2}\right), \quad 128.90 / 128.79 \quad(2 \mathrm{C}, \mathrm{Ph})$, 128.22/127.93 (2C, Ph), 123.47/123.37 $\left(\mathrm{Ph}\left(\mathrm{CH}_{3}\right)_{2}\right), 80.07 / 79.86$ (C-2), 78.19/77.59 (C-1), 59.60/59.29, 30.37/30.01, 29.77/29.64, 23.47/23.41, 23.36/23.31, 17.34/17.28 (2C, $\left.\mathrm{CH}_{3}\right)$. HRMS: $m / z$ calculated for $\mathrm{C}_{22} \mathrm{H}_{26} \mathrm{ClO}_{3}[\mathrm{M}+\mathrm{H}]^{+} 373.1565$, found $373.1553 ; \mathrm{m} / z$ calculated for $\mathrm{C}_{14} \mathrm{H}_{19} \mathrm{O}\left[\mathrm{M}+\mathrm{H}-\mathrm{HO}_{2} \mathrm{C}-\mathrm{CH}\left(\mathrm{CH}_{3}\right) \mathrm{Cl}\right]^{+}$203.1431, found $203.1440 ; \mathrm{m} / \mathrm{z}$ calculated for $\mathrm{C}_{14} \mathrm{H}_{16} \mathrm{ClO}_{2}\left[\mathrm{M}+\mathrm{H}-\mathrm{HOPh}\left(\mathrm{CH}_{3}\right)_{2}\right]^{+}$251.0834, found $251.0851 ; \mathrm{m} / \mathrm{z}$ calculated for $\mathrm{C}_{22} \mathrm{H}_{29} \mathrm{ClNO}_{3}\left[\mathrm{M}+\mathrm{NH}_{4}\right]^{+} 390.1836$, found 390.1880 .

Compound ( \pm )-32 $[( \pm)$-(trans-2-(cyclohexyloxy)cyclohexyl 2-chloro-2-phenylethanoate]. Mixture of diastereomers (ratio of diastereomers determined using signal for H-2 at 4.78/4.74 ppm). Isolated via column chromatography ( $\left.\mathrm{Rf} 0.48, \mathrm{CH}_{2} \mathrm{Cl}_{2}\right)$. Clear colorless oil. ${ }^{1} \mathrm{H} \mathrm{NMR}(600$ $\mathrm{MHz}, \mathrm{CDCl}_{3}$ ): $\delta(\mathrm{ppm}) 7.49(\mathrm{~m}, 2 \mathrm{H}, \mathrm{Ph}), 7.36$ (m, 3H, Ph), 5.32/5.32 (s, CHPhCl), 4.78/4.74 $(\mathrm{m}, 1 \mathrm{H}, \mathrm{H}-2), 3.33 / 3.29(\mathrm{~m}, 1 \mathrm{H}), 3.25 / 3.16(\mathrm{~m}, 1 \mathrm{H}), 2.1-1.0(\mathrm{~m}, 18 \mathrm{H}) .{ }^{13} \mathrm{C}$ NMR $(150 \mathrm{MHz}$, $\left.\mathrm{CDCl}_{3}\right): \delta 167.78 / 167.73(\mathrm{C}=\mathrm{O}), 136.20 / 136.13\left(\mathrm{C}_{\mathrm{q}}, \mathrm{Ph}\right), 129.27 / 129.18(\mathrm{Ph}), 128.91 / 128.82$ (2C, Ph), 128.10/128.04 (2C, Ph), 78.15/77.84 (C-2), 76.92/76.87, 76.23/76.12, 59.59/59.55, $33.43 / 33.25,32.68 / 32.39,31.57 / 31.34,29.92 / 29.47,25.81 / 25.71,24.38 / 24.32,23.55 / 23.38$, 23.43/23.23. HRMS: $m / z$ calculated for $\mathrm{C}_{20} \mathrm{H}_{28} \mathrm{ClO}_{3}[\mathrm{M}+\mathrm{H}]^{+} 351.1722$, found 351.1738.

Compound $( \pm)$-33 [( \pm -(trans-2-(p-tolylsulfonyl)cyclohexyl 2-chloro-2-phenylethanoate]. Mixture of diastereomers (ratio of diastereomers determined using signal for H-1 at 5.05/4.94 $\mathrm{ppm})$. Isolated via column chromatography (F12-13: $\mathrm{R}_{\mathrm{f}} 0.27, \mathrm{~F} 15-16: \mathrm{R}_{\mathrm{f}} 0.31,8: 2$ hexane:ethyl acetate). Clear colorless oil. ${ }^{1} \mathrm{H}$ NMR $\left(600 \mathrm{MHz}, \mathrm{CDCl}_{3}\right): \delta(\mathrm{ppm})$ 7.8-7.2 (m, $9 \mathrm{H}$, Ar), 5.09/4.62 (s, CHClPh), 5.05/4.94 (dt, 4.5 Hz, 9.9 Hz, H-1), 3.29/3.18 (ddd, 4.8 Hz, 9.0 Hz, 10.8 $\mathrm{Hz}, \mathrm{H}-2), 2.49 / 2.42$ (s, 3H, tolyl- $\left.\mathrm{CH}_{3}\right), 2.31 / 2.13(\mathrm{~m}, 2 \mathrm{H}), 1.92-1.64(\mathrm{~m}, 2 \mathrm{H}), 1.64-0.8(\mathrm{~m}, 4 \mathrm{H})$. ${ }^{13} \mathrm{C}$ NMR $\left(150 \mathrm{MHz}, \mathrm{CDCl}_{3}\right): \delta$ 167.29/166.83 $(\mathrm{C}=\mathrm{O}), 144.87 / 144.83\left(\mathrm{C}_{\mathrm{q}, \mathrm{Ar}} \mathrm{S}\right), 136.50 / 135.34$ $\left(\mathrm{C}_{\mathrm{q}}\right), 135.78 / 135.23\left(\mathrm{C}_{\mathrm{q}}\right), 130.00 / 129.88,129.43 / 129.31,128.95 / 128.80,128.72 / 128.40,127.75$, 72.44/72.33 (C-1), 65.44/64.90 (C-2), 59.20/58.36 ( $\left.\mathrm{CH}\left(\mathrm{CH}_{3}\right) \mathrm{Cl}\right), 30.64 / 30.53,25.12 / 24.36$, 
23.93/23.74, 23.05/22.91, 21.77/21.75. HRMS: $m / z$ calculated for $\mathrm{C}_{21} \mathrm{H}_{24} \mathrm{ClO}_{4} \mathrm{~S}[\mathrm{M}+\mathrm{H}]^{+}$ 407.1079, found 407.1084; $\mathrm{m} / z$ calculated for $\mathrm{C}_{21} \mathrm{H}_{27} \mathrm{ClNO}_{4} \mathrm{~S}\left[\mathrm{M}+\mathrm{NH}_{4}\right]^{+}$424.1344, found 424.1308; $\mathrm{m} / z$ calculated for $\mathrm{C}_{13} \mathrm{H}_{17} \mathrm{O}_{2} \mathrm{~S}\left[\mathrm{M}+\mathrm{H}-\mathrm{HO}_{2} \mathrm{CCHCl}\left(\mathrm{C}_{6} \mathrm{H}_{5}\right)\right]^{+}$237.0944, found 237.0943; $m / z$ calculated for $\mathrm{C}_{42} \mathrm{H}_{47} \mathrm{Cl}_{2} \mathrm{O}_{8} \mathrm{~S}_{2}\left[\mathrm{M}+\mathrm{H}-\mathrm{HO}_{2} \mathrm{CCHCl}\left(\mathrm{C}_{6} \mathrm{H}_{5}\right)\right]^{+}$813.2084, found 813.1933.

Compound $( \pm)$-34 [( $( \pm)$-trans-2-(methyl)cyclohexyl 2-chloro-2-phenylethanoate]. Mixture of diastereomers (ratio of diastereomers determined using signal for $\mathrm{CH}(\mathrm{Ph}) \mathrm{Cl}$ at 5.34/5.33 ppm). Isolated via column chromatography ( $\mathrm{Rf}$ 0.54, 95:5 hexane:ethyl acetate). Clear yellow oil. ${ }^{1} \mathrm{H}$ NMR (600 MHz, $\left.\mathrm{CDCl}_{3}\right)$ : $\delta(\mathrm{ppm}) 7.19(\mathrm{~m}, 2 \mathrm{H}, \mathrm{Ph}), 7.35(\mathrm{~m}, 3 \mathrm{H}, \mathrm{Ph}), 5.34 / 5.33(\mathrm{~s}, \mathrm{CH}(\mathrm{Ph}) \mathrm{Cl})$, 4.46/4.43 (dt, 4.2 Hz, 10.2 Hz, H-1), 1.98/1.85 (m, 1H), $1.73(\mathrm{~m}, 1 \mathrm{H}), 1.68(\mathrm{~m}, 1 \mathrm{H}), 1.62-1.45$ $(\mathrm{m}, 2 \mathrm{H}), 1.35-1.11(\mathrm{~m}, 3 \mathrm{H}), 1.03(\mathrm{~m}, 1 \mathrm{H}), 0.86 / 0.63\left(\mathrm{~d}, 6.6 \mathrm{~Hz}, 3 \mathrm{H}, \mathrm{CH}_{3}\right) .{ }^{13} \mathrm{C} \mathrm{NMR}(150 \mathrm{MHz}$, $\left.\mathrm{CDCl}_{3}\right): \delta(\mathrm{ppm}) 168.15\left(\mathrm{C}_{\mathrm{q}}, \mathrm{C}=\mathrm{O}\right), 136.27 / 136.06\left(\mathrm{C}_{\mathrm{q}}, \mathrm{Ph}\right), 129.25 / 129.22(\mathrm{Ph}), 128.85 / 128.82$ $(2 \mathrm{C}, \mathrm{Ph}), 127.99 / 127.97(2 \mathrm{C}, \mathrm{Ph}), 81.02 / 80.92(\mathrm{C}-1), 59.76 / 59.45(\mathbf{C H}(\mathrm{Ph}) \mathrm{Cl}), 37.25 / 37.11$, 33.43, 31.50/31.12, 25.22/25.16, 24.67/24.56, 18.37/18.03 $\left(\mathrm{CH}_{3}\right)$. HRMS: $m / z$ calculated for $\mathrm{C}_{15} \mathrm{H}_{20} \mathrm{ClO}_{2}[\mathrm{M}+\mathrm{H}]^{+}$267.1147, found 267.1139; $\mathrm{m} / z$ calculated for $\mathrm{C}_{7} \mathrm{H}_{13}\left[\mathrm{M}+\mathrm{H}-\mathrm{HO}_{2} \mathrm{C}-\right.$ $\mathrm{CH}(\mathrm{Ph}) \mathrm{Cl}]^{+}$97.1012, found 97.1017; $\mathrm{m} / \mathrm{z}$ calculated for $\mathrm{C}_{15} \mathrm{H}_{23} \mathrm{ClNO}_{2}\left[\mathrm{M}+\mathrm{NH}_{4}\right]^{+}$284.1417, found 284.1370 .

Molecular modeling. Computations were performed using the CambridgeSoft ChemBioDraw 3D Ultra 12.0 program suite. The initial structures were constructed from the ester product with permanent configurations at C-2 of the acyl group as well as C-1 and C-2 of the cyclohexane ring. Subsequently, with the assumption that the transition state resembles the product to some extent (Eyring-Evans-Polanyi theory), a chlorine (or pyridinium) was introduced at the ester carbonyl, whose bond order was reduced from 2 to 1 and the formal oxidation state of oxygen was changed to -1 . Variation of the transient configuration of the transition state carbon as well as of the permanent configuration on the acyl group resulted in all diastereomeric permutations. The corresponding enantiomeric structures were not considered computationally. The structures were then subjected to exhaustive dihedral angle searches for both substituents and were minimized into the global minima in the MM2 force field. Both R- and S-configurations of the transient sp3-carbon were considered. From this, the geometry was optimized without restrictions towards the transition state by the semi-empirical AM1 method initially, followed by subsequent geometry optimization at the B3LYP/3-21G and B3LYP/6-311G levels of theory. For the transition states including pyridine catalyst, the same method was used except that the formal charge at the pyridinium nitrogen was +1 and the formal charge at the oxygen was -1 . Extended Hückel calculations generated the molecular orbitals for each structure. The xyzcoordinates of the lowest computed transition states for all pertinent diastereomeric permutations and the 2D representations of their LUMO are supplied in the Supplemental Material. 


\section{Acknowledgements}

The authors thank the National Science Foundation and a Major Research Instrumentation grant (CHE-0722654) for the funding of the JEOL ECA-600 NMR spectrometer. We also thank the Department of Chemistry at the University of the Pacific for financial support. We are thankful to Drs. Vyacheslav V. Samoshin and Mamoun M. Alhamadsheh for helpful suggestions and discussion.

\section{References}

1. Storch, G.; Trapp, O. Angew. Chem. Int. Ed. 2015, 54, 3580-3586. http://dx.doi.org/10.1002/anie.201412098

2. Ivšić, T.; Novak, J.; Došlić, N.; Hameršak, Z. Tetrahedron 2012, 68, 8311-8317. http://dx.doi.org/10.1016/j.tet.2012.07.035

3. Guan, Y.; López-Alberca, M. P.; Lu, Z.; Zhang, Y.; Desai, A. A.; Patwardhan, A. P.; Dai, Y.; Vetticatt, M. J.; Wulff, W. D. Chem. Eur. J. 2014, 20, 13894-13900. http://dx.doi.org/10.1002/chem.201404587

4. Kalck, P.; Urrutigoity, M. Coord. Chem. Rev. 2004, 248, 2193-2200. http://dx.doi.org/10.1016/j.ccr.2004.05.001

5. Arseniyadis, S.; Valleix, A.; Wagner, A.; Mioskowski, C. Angew. Chem. Int. Ed. Engl. 2004, 43, 3314-3317. http://dx.doi.org/10.1002/anie.200453956

6. Toueg, J. P., Prunet, J. Org. Lett. 2008, 10, 45-48. http://dx.doi.org/10.1021/o1702566c

7. Garzan, A.; Jaganathan, A.; Salehi Marzijarani, N.; Yousefi, R.; Whitehead, D. C.; Jackson, J. E.; Borhan, B. Chem. Eur. J. 2013, 19, 9015-9021.

http://dx.doi.org/10.1002/chem.201300189

8. Sanji, T. T., M. Organometallics 2006, 25, 6159-6161. http://dx.doi.org/10.1021/Om060671r

9. Ordóñez, M.; Hernández-Fernández, E.; Rojas-Cabrera, H.; Labastida-Galván, V. Tetrahedron: Asymmetry 2008, 19, 2767-2770.

http://dx.doi.org/10.1016/j.tetasy.2008.11.028

10. Martinez-Castaneda, A.; Rodriguez-Solla, H.; Concellon, C.; del Amo, V. J. Org. Chem. 2012, 77, 10375-10381.

http://dx.doi.org/10.1021/jo3020352

11. Leclercq, L.; Suisse, I.; Agbossou-Niedercorn, F. Eur. J. Org. Chem. 2010, 2010, 2696-2700. http://dx.doi.org/10.1002/ejoc.200901075

12. Kawabata, T. N., M.; Takasu, K.; Fuji, K. J. Am. Chem. Soc. 1997, 119, 3169-3170. http://dx.doi.org/10.1021/Ja963275g 
13. Samoshin, A. V. V., J.; Curtis, M.; Samoshin, V.V.; Franz, A.H. ARKIVOC 2012, 8, 27-35. http://dx.doi.org/10.3998/ark.5550190.0013

14. Watson, A.; Hackbusch, S.; Samoshin, V.V.; Franz, A.H. JUCR 2014, 13, 38-42.

15. Lambert, J. B. B., B.M.; Kuang, K. J. Org. Chem. 1999, 64, 9241-9245. http://dx.doi.org/10.1021/Jo991536

16. Al Hazmi, A. M.; Sheikh, N. S.; Bataille, C. J. R.; Al-Hadedi, A. A. M.; Watkin, S. V.; Luker, T. J.; Camp, N. P.; Brown, R. C. D. Org. Lett. 2014, 16, 5104-5107. http://dx.doi.org/10.1021/o1502454r 